\title{
Copper (II)-based halogen -substituted chromone antitumor drug entities: Studying biomolecular interactions with ct-DNA mediated by sigma hole formation and cytotoxicity activity.
}

Farukh Arjmand, ${ }^{\text {a* Salman khursheed, }}{ }^{\mathrm{a}}$ Thierry Roisnel, ${ }^{\mathrm{b}}$ Hifzur R. Siddique ${ }^{\mathrm{c}}$

${ }^{a}$ Department of Chemistry, Aligarh Muslim University, Aligarh, India.

'Institut des Sciences Chimiques de Rennes, UMR 6226, Universit'e de Rennes 1, Campus de Beaulieu Batiment 10B, Bureau, 15335042 Rennes, France

${ }^{c}$ Cytogenetics and Molecular Toxicology Laboratory, Section of genetics, Department of Zoology, Aligarh Muslim University, Aligarh, 202002, Uttar Pradesh, India

E-mail: farukh_arjmand@yahoo.co.in; Tel: +91 5712703893

\begin{abstract}
Copper-based antitumor drug entities 1-3 derived from substituted $\left(\mathrm{F}^{-}, \mathrm{Br}^{-}, \mathrm{CH}_{3}\right)$ 3formylchromone pharmacophore were synthesized and thoroughly characterized by spectroscopic and single X-ray crystallographic studies. These complexes show structural novelty due to presence of the X-bonds in chromone scaffold which could facilitate higher propensity for nucleic acids via sigma $\sigma$-hole interactions. Therefore, structure-activity relationship of 1-3 was studied by performing ct-DNA binding, pBR322 cleavage and cytotoxicity activity to validate their potential to act as chemotherapeutic drug entities. The binding studies of 1-3 with ct- DNA were carried out employing many biophysical techniques and the corroborative results of these experiments showed intercalation mode of binding and the order of binding was found to be 2 $>\mathbf{1}>\mathbf{3}$. The structure of drug entities could facilitated strong halogen bonding interaction(in case of $1 \& 2$ ) and stability of $X$ bond was rationalized by sigma hole region of positive electrostatic potential on the surface of C-X covalent bond, as determined by gas phase B3LYP computational DFT studies. Interestingly, 2 exhibited most avid binding affinity due to presence of $\mathrm{Br}^{-}$electron withdrawing and polarizable group. Further, cleavage studies of 1-3 with pBR322 plasmid DNA were performed which demonstrated significant cleavage activity, the supercoiled form (Form
\end{abstract}


I) of plasmid DNA was converted to nicked form (Form II) with the appearance of linearized form(Form III) in between two, implicating lethal double strand breaks of DNA. 2 showed predominantly higher cleavage activity following the similar trend as observed for binding studies. The cytotoxicity of the complexes 1-3 was evaluated by MTT assay against the human liver carcinoma (Huh-7) and prostate cancer (DU-145) cell lines; complex 2 exhibited specific and selective cytotoxicity for the DU-145 cancer cell line with $\mathrm{LC}_{50}$ value of $1.6 \mu \mathrm{M}$.

\section{Introduction}

Copper is an endogenously biocompatible trace element which plays a key role in many vital enzymes in biological system [1]. Copper complexes exhibit interesting chemical and biological properties viz., strong Lewis acid nature, redox active behavior with one electron $\mathrm{Cu}(\mathrm{II}) / \mathrm{Cu}(\mathrm{I})$ shuttle, high binding propensity for DNA, DNA cleaving ability via an oxidative pathway, antitumor and apoptosis inducing character [2-5]. Copper complexes have emerged as potent class of future generation anticancer agents, primarily due to their differential response towards cancerous and normal cells. Copper was found to be a co-factor for several angiogenesis mediators including vascular endothelial growth factor(VEGF) [6], basic fibroblast growth factor (bFGF) [ 7], interleukin-1 (IL-1) and IL-8 [8]. Tumors are dependent on angiogenesis for their growth, invasion and metastasis [9], since tumor cells are in a state of hypoxia due to altered metabolism and rapid growth. Furthermore, copper content is usually much higher in cancerous cells as compared to normal cells. Many copper complexes are also known to induce oxidative stress by the production of ROS or the depletion of GSH due to cellular accumulation of the redox active copper ions [10].

Chromones- benzoannelated $\gamma$-pyrone heterocycles are considered as versatile privileged scaffolds in medicinal chemistry owing to their diverse pharmacological applications $[11,12]$. They are 
excellent templates for the design of novel pharmacologically important compounds due to ease of substitution and structure modification. Therefore, many substituted derivatives of 3-formyl chromones have been synthesized and explored for medicinal properties for treating chronic neurodegenerative, inflammatory, and infectious diseases as well as diabetes and cancer [13-15]. Chromone based compounds have been incorporated in cancer- targeted therapeutic drug molecules which were capable of inhibiting different types of cancer targets, viz., TNF $\alpha$ signaling and protein kinases [16]. Copper (II) chromone complexes have shown cytotoxicity against different phenotypes of cancer cell lines with varied potencies [17-19]. The cytotoxic activity of $\mathrm{Cu}(\mathrm{II})$ chromone Schiff base complexes on cell proliferation of chemoresistant lung cancer (A549) and breast (MCF-7) cancer cell line was evaluated and the complexes were capable of effectively overcoming cisplatin resistance in these cell lines which was attributed to chelation of the chromone ligand with metal ion [20]. In our laboratory, the cytotoxic potential of chromone$\mathrm{Cu}(\mathrm{II})$ drug candidates was evaluated on human breast (MCF-7) and liver cancer (HepG2) cell lines which revealed good cytotoxic response at significantly lower $\mathrm{IC}_{50}$ values of $(5-10 \mu \mathrm{g}$ $\left.\mathrm{mL}^{-1}\right)[21]$

Recently, halogen bonding has fueled much interest in the subdomain area of small moleculenucleic acid interactions in medicinal inorganic chemistry [22]. Halogen bonding is a type of charge transfer interaction which is a qualitative analogue of hydrogen bonding [23, 24]. The halogen bonds take place between a halide $(\mathrm{X})$ in one molecule with neighboring electron-rich Lewis base site, similar to a hydrogen bonds. DNA is most amenable therapeutic drug target for many antitumor drugs in clinical use which possesses several easily accessible electron rich reactive sites such as nucleobase pairs and ribose sugar- phosphate backbone of double helix. Interaction of small molecules with X-bond with DNA double helix could be interpreted on the 
basis of halogen bonding , as formation of the halogen bond is thermodynamically more favorable and can be thus, be used to predict non-covalent interactions such as electrostatic interactions, groove binding and intercalation. Halogens in organic and inorganic compounds are known to polarize their covalent bonds to generate electropositive crown where the halogen acts as a Lewis acid to pair with Lewis bases, including oxygen and nitrogen atoms of biomacromolecules. These electrostatic pairs known as halogen bonds or X-bonds could contribute immensely to the understanding of drug-nucleic acid interactions [25]

We describe herein, new copper (II) based antitumor drug candidates 1-3 derived from substituted chromone scaffold where $\mathrm{X}=\mathrm{F}^{-}, \mathrm{Br}$, and $-\mathrm{CH}_{3}$. The substitution of halogens and alkyls in chromone scaffold drastically alters the physiochemical and pharmacological properties of drug entities in following ways: i) They can affect the polarity and lipophilicity which enable the facile transportation/permeation via the cell membrane into the cells thus preventing off-target toxicity ii) prolong the lifetime of active metabolite iii) show cytotoxic response at low submicromolar dosage iv) inhibit cell proliferation by targeting TNF $\alpha$-signaling and protein kinases. Besides, copper(II) embedded in bioactive chromone pharmacophore also plays a significant role by inducing ROS oxidative stress and mediating angiogenesis. We have evaluated the DNA binding affinity of $\mathrm{Cu}(\mathrm{II})$ chromone complexes $\mathbf{1 - 3}$ by a battery of biophysical methods. Since these complexes possess the X-bonds which could facilitate sigma $\sigma$-hole interactions, it was considered worthwhile to study their in vitro differential response with ct- DNA and cytotoxicity in cancerous cells. The present $\mathrm{Cu}(\mathrm{II})$ complexes- DNA model system demonstrated that among all X-bonds, bromine substituted chromone $\mathrm{Cu}(\mathrm{II})$ complex 2 exhibited avid binding propensity with DNA and exhibited selective cytotoxicity for the DU-145 cancer cell line at a low intracellular concentration. 


\section{Results and discussion}

\section{Synthesis and characterization}

The copper (II) complexes 1-3 derived from substituted (F-, Br-, -- $\mathrm{CH}_{3}$ ) 3-formylchromone were synthesized and thoroughly characterized by elemental analysis and various other spectroscopic techniques viz., UV-vis, FT-IR, EPR and ESI-MS (Scheme 1). The molecular structure of complexes 1-3 was confirmed by single X-ray diffraction studies. The synthesis of the complexes involved formation of an in situ intermediate (3-hydroxymethylene-2-ethoxychroman-4-one) via ethoxylation at the 2- position of the chromone derivatives $\left(\mathrm{F}^{-}, \mathrm{Br}^{-},-\mathrm{CH}_{3}\right)$. The synthesized complexes were air-stable and soluble in organic solvents such as EtOH, DCM, acetone, DMF and DMSO.

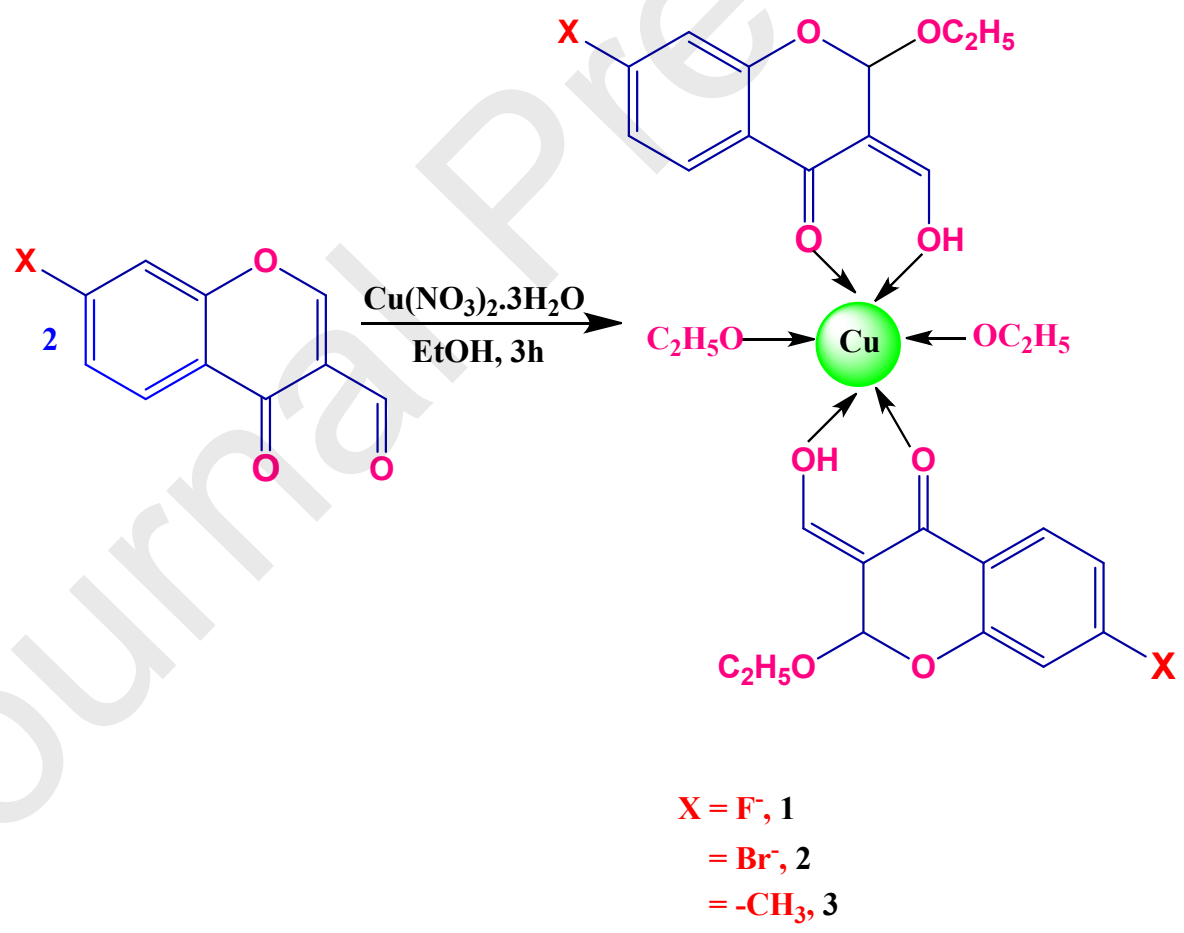

Scheme 1 Synthetic route for complexes 1, 2 and 3

Spectroscopic characterization 
In the IR spectra of complexes $\mathbf{1}-\mathbf{3}$, the characteristic bands assigned to $v(\mathrm{HC}=\mathrm{O})$ and $v(-\mathrm{C}=\mathrm{O})$ of 3-formylchromone derivatives observed at 1694 and $1671 \mathrm{~cm}^{-1}$,respectively were shifted to lower wave number by $15-25 \mathrm{~cm}^{-1}$ indicating the complexation of these groups with metal ions (Fig. S1) [26]. The bands which appeared at $592 \mathrm{~cm}^{-1}$ and $1263 \mathrm{~cm}^{-1}$ were assigned to $v(\mathrm{C}-\mathrm{Br})$ and $v(\mathrm{C}-\mathrm{F})$ stretching vibrations, respectively. In complex 3, two characteristic bands at $2907 \mathrm{~cm}^{-1}$ and 3069 $\mathrm{cm}^{-1}$ corresponded to $\mathrm{sp}^{2}$ and $\mathrm{sp}^{3}$ hybridized carbon atoms, respectively. The band at $1060 \mathrm{~cm}^{-1}$ was attributed to $v(\mathrm{C}-\mathrm{O})$ stretch, indicating the ethoxylation of the 3-formylchromone derivative at 2-position. In the far-IR of complexes 1-3, the metal coordination was substantiated by the bands at $426-500 \mathrm{~cm}^{-1}$.

The solid state X-band EPR spectra of complexes 1-3 were recorded at room temperature on 9.1 GHz frequency under the magnetic field strength of $3000 \mathrm{G}$ (Fig. S2). The EPR spectra of 1-3 displayed the anisotropic band centered at $\mathrm{g}$ values as shown in Table S4. These values are in agreement with tetragonally elongated octahedral geometry of $\mathrm{Cu}$ (II) ion with $\mathrm{d}^{9}$ configuration [27] i.e. $(\mathrm{eg})^{4} \cdot\left(\mathrm{a}_{1} \mathrm{~g}\right)^{2} \cdot\left(\mathrm{b}_{2} \mathrm{~g}\right)^{2} \cdot\left(\mathrm{b}_{1} \mathrm{~g}\right)^{1}$. The trend of $\mathrm{g}$-tensor values is $\mathrm{g} \|>\mathrm{g} \perp>2.0023$ suggested that unpaired electron mainly resides in $\mathrm{dx}^{2}-\mathrm{y}^{2}$ orbital. Furthermore, the complexes possess $\mathrm{g}_{\|}<2.3$, revealing an appreciable metal-ligand covalent character of the complexes [28, 29].

Electronic spectra of complexes 1-3 were recorded in DMSO at room temperature which revealed two well resolved absorption maxima in the range 260 to $290 \mathrm{~nm}$ and $300-315 \mathrm{~nm}$ attributed to $\pi$ $\pi^{*}$ and $n-\pi^{*}$ electronic transitions, respectively. Broad $d-d$ bands observed in the visible part of spectra in the range 400-642 $\mathrm{nm}$ are typical for tetragonally distorted octahedral environment around the $\mathrm{Cu}(\mathrm{II})$ center [30]. 


\section{Description of the X-ray crystal structures}

The complex 1 crystallizes in the monoclinic space group $P 21 / n$ possessing the lattice parameters $\mathrm{a}=9.9291(4) \mathrm{A}^{0}, \mathrm{~b}=5.1435(2) \mathrm{A}^{0}, \mathrm{c}=27.7256(10) \mathrm{A}^{0}$ and $\alpha=\gamma=90^{0}, \beta=98.1990(10)^{0}$. The complex shows slight distorted octahedral geometry $\mathrm{CuO}_{6}$ coordination environment with ligation from four carbonyl oxygen $[\mathrm{Cu}-\mathrm{O}=1.9325(12)]$ of fluoro substituted chromone ligand scaffold and two oxygen $[\mathrm{Cu}-\mathrm{O}=1.958(13)]$ from solvate ethanol moiety. The bond lengths of $\mathrm{Cu}-\mathrm{O}$ at axial positions were slightly larger due to static Jahn-Teller distortion. Further extension of the crystal structure occurs through $\pi-\pi$ stacking interactions, resulting in the $3 \mathrm{D}$ supramolecular architecture as shown in Fig. 1.

The ORTEP view of the complex 2 is shown in Fig. 1. The O-O donor bromine substituted formylchromone ligand scaffold binds to the $\mathrm{Cu}$ (II) ion to form 6-membered chelate rings. Due to static Jahn-Teller distortion, there was considerable variations in equatorial and axial bond lengths. The complex crystallized in the triclinic system in $P-1$ space group. The optimized lattice parameters are $\mathrm{a}=5.1134$ (5) $\AA, \mathrm{b}=9.7980$ (9) $\AA, \mathrm{c}=14.9650$ (14) $\AA$ and $\alpha=85.415$ (3) ${ }^{\circ}, \beta=$ $83.430(3)^{\circ}, \gamma=89.988(4)^{\circ}$.

Single crystal X-ray study of complex $\mathbf{3}$ revealed that it crystallized in the triclinic $P-1$ space group possessing the lattice parameters, $\mathrm{a}=5.1349$ (4) $\mathrm{A}^{0}, \mathrm{~b}=11.6066(9) \mathrm{A}^{0}, \mathrm{c}=12.9630(11) \mathrm{A}^{0}$ and $\alpha=105.733(3)^{0}, \beta=97.741(3)^{0}, \gamma=90.384(3)^{0}$ per unit cell. An ellipsoid view of complex 3 along with atom numbering scheme is depicted in fig. 1. The structure of complex $\mathbf{3}$ represent a centrosymmetric $\mathrm{Cu}$ (II) ion coordinated to a methyl substituted chromone ligand scaffold through O,O-atoms with a solvate ethoxy group at 2-position along with two ethanol moieties at the axial position. All the $\mathrm{Cu}-\mathrm{O}$ bond distances in complexes 1-3 were observed within the range reported for other $\mathrm{Cu}$ (II) octahedral complexes [31]. 
Other crystallographic data viz., selected bond lengths and bond angles for 1-3 are summarized in Table S1-S3.

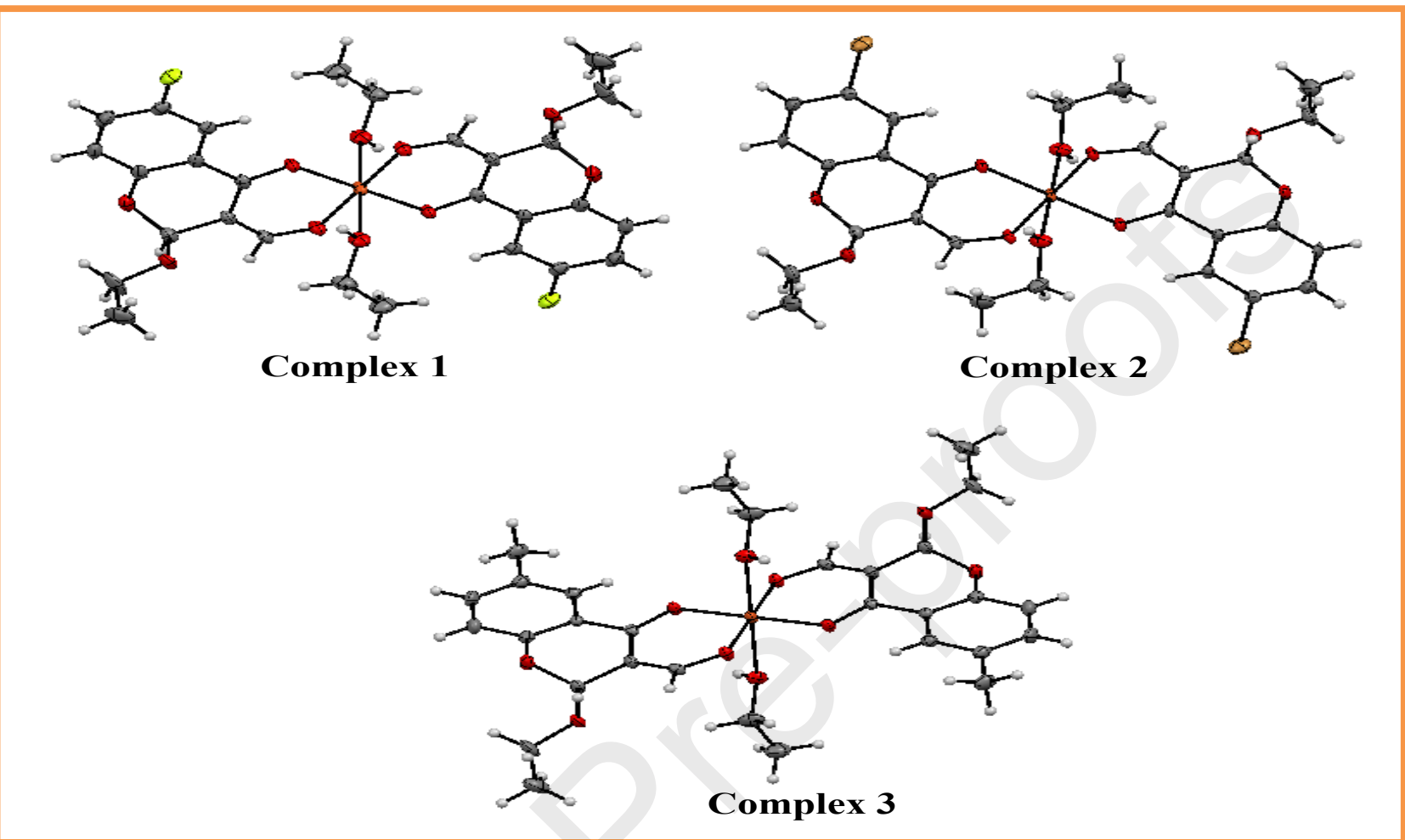

Fig. 1. Single crystal X - ray structure of complexes $\mathbf{1}-\mathbf{3}$ (50\% probability ellipsoids).

\section{DNA binding studies}

Metal-based drug candidates can uncoil the helical structure of ct-DNA, undrape the embedded electron rich nucleobases to the exterior helix leading to an efficacious binding with the drug entities either in covalent or non- covalent binding mode viz., electrostatic, groove binding and intercalation $[29,32]$. The binding of copper(II)-based halogen substituted-chromone derivatives 1-3 with ct-DNA was followed by a battery of different complementary techniques such as UVvis absorption, florescence spectroscopy, EPR spectroscopy, circular dichorism and cyclic voltammetry. 
Electronic absorption titration of complexes 1-3 was carried out in presence and in the absence of ct-DNA at room temperature (Fig. 2). Upon addition of increasing concentration $\left(0.00-3 \times 10^{-5} \mathrm{M}\right)$ of ct-DNA to a fixed concentration $\left(2 \times 10^{-4} \mathrm{M}\right)$ of $\mathbf{1 - 3}$, a sequential decrease of the absorption intensity was observed at the intra-ligand band at 250-300 nm exhibiting "hypochromism" of $43 \%$ in case of $\mathbf{1}, 54 \%$ for $\mathbf{2}$ and $41 \%$ for $\mathbf{3}$, respectively. There was a pronounced red shift of 7-8 $\mathrm{nm}$ in complexes $\mathbf{1}$ and $\mathbf{2}$, suggesting intercalative mode of binding while a moderate shift of 1-2 $\mathrm{nm}$ was observed in case of $\mathbf{3}$ which implicated groove binding mode [33]. The rationale for intercalation mode of binding in complexes $1 \& 2$ is presence of aromatic $\pi$ - $\pi$ stacking chromophore which could easily "slip in" or insert between the nucleobases while $\mathbf{3}$ articulates groove binding due to the non-planarity of the methyl groups, therefore prefers to bind by electrostatic interaction to the negatively charged phosphate oxygen of DNA helix. The binding strengths of 1-3 with ct-DNA was quantified by the intrinsic binding constant $K_{b}$, using the WolfeShimer equation (1) [34].

$$
[D N A] / \epsilon_{\mathrm{a}}-\epsilon_{\mathrm{f}}=[\mathrm{DNA}] / \epsilon_{\mathrm{b}}-\epsilon_{\mathrm{f}}+1 / K_{\mathrm{b}}\left(\epsilon_{\mathrm{b}}-\epsilon_{\mathrm{f}}\right)
$$

Where [DNA] is the ct-DNA concentration and $\epsilon_{\mathrm{a}}, \epsilon_{\mathrm{f}, \text { and }} \epsilon_{\mathrm{b}}$ are apparent $\left(\mathrm{A}_{\mathrm{abs}} /[\mathrm{Cu}\right.$ (II) complex]), free and bound complex molar absorptivity coefficients, respectively. From the plot of [DNA/ $\epsilon_{\mathrm{a}^{-}}$ $\left.\epsilon_{f}\right]$ vs [DNA] with a slope of $1 /\left(\epsilon_{b}-\epsilon_{f}\right)$ and intercept of $1 /\left[K_{b}\left(\epsilon_{a}-\epsilon_{f}\right)\right]$, the values of $K_{b}$ were derived by the ratio of slope to intercept. 


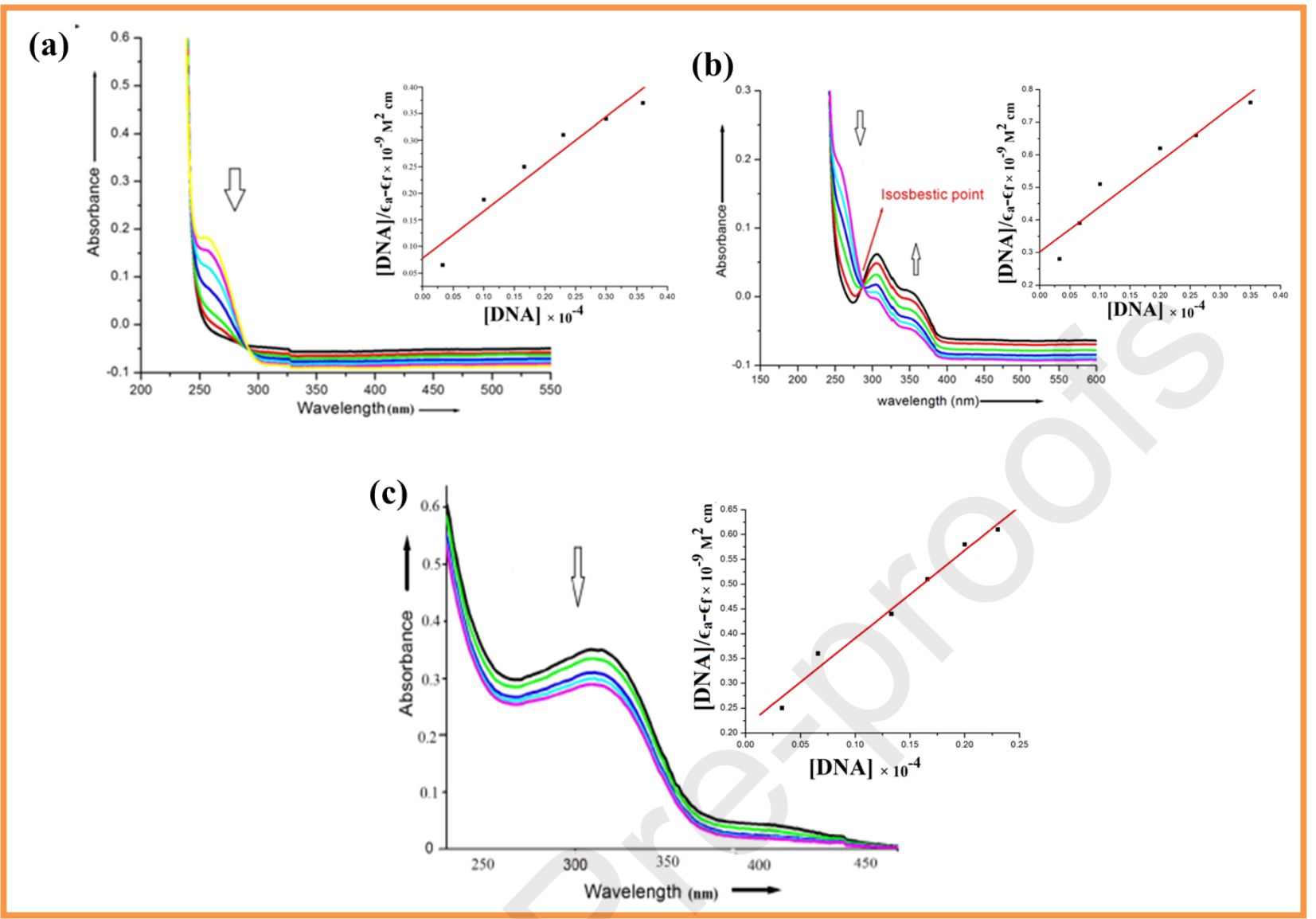

Fig. 2. Absorption spectra of complexes 1 (a), 2 (b) and 3 (c) in absence and presence of increasing concentrations of ct-DNA in Tris - $\mathrm{HCl}$ buffer $(\mathrm{pH}=7.3)$. Inset: plots of [DNA]/( $\epsilon_{\mathrm{a}}-\epsilon_{\mathrm{f}}\left(\mathrm{M}^{2} \mathrm{~cm}\right) \mathrm{vs}$ [DNA] for the absorption titration with 1-3. The arrows specify the change (increase/decrease) in intensity of absorbance with increasing ct-DNA.

Table 2 The binding constant values for complexes 1-3 obtained upon interaction with ct-DNA.

\section{Emission spectra}

Complex

Absorption spectra, $K_{b}\left(\times 10^{4} \mathrm{M}^{-1}\right) \quad \frac{K\left(\times 10^{4} \mathrm{M}^{-1}\right)}{K_{s v}\left(\times 10^{4} \mathrm{M}^{-1}\right)}$

\begin{tabular}{|c|c|c|c|c|}
\hline 1 & ct-DNA & $6.46( \pm 0.3)$ & $6.97( \pm 0.05)$ & $5.04( \pm 0.03)$ \\
\hline 2 & ct-DNA & $7.58( \pm 0.1)$ & $7.23( \pm 0.02)$ & $6.13( \pm 0.05)$ \\
\hline 3 & ct-DNA & $4.33( \pm 0.4)$ & $4.93( \pm 0.07)$ & $4.19( \pm 0.01)$ \\
\hline
\end{tabular}


The intrinsic binding constant, $K_{b}$ values of the complexes 1-3 with ct-DNA are depicted in Table 2 and were found to be in the order of magnitude $2>\mathbf{1}>\mathbf{3}$. Interestingly, the $K_{b}$ values of $1 \& 2$ were found to be two-fold higher in magnitude as compared to complex 3 which has been attributed to the presence of halogens on their ligand scaffolds as halogen substituents provide hydrophobic, polar and planar environment suitable for intercalation with ct-DNA [35]. Notably, bromine substituted complex 2 revealed highest binding affinity towards DNA, which can be envisaged by a model that shows that the electron density from DNA nucleobases could be directly transferred to polarizable $\mathrm{C}$ - $\mathrm{Br}$ bond of ligand scaffold via the sigma $\sigma$ - hole (Fig. 3) with further "proof of concept" obtained by docking and computational B3LYP /DFT studies [36]. Albeit no such observation was seen in case of fluorine- substituted moiety of 1 while the complex $\mathbf{3}$ exhibited lowest $K_{b}$ value with ct-DNA which can be explained by the lack of planarity and steric hindrance due to methyl group present on ligand moiety.

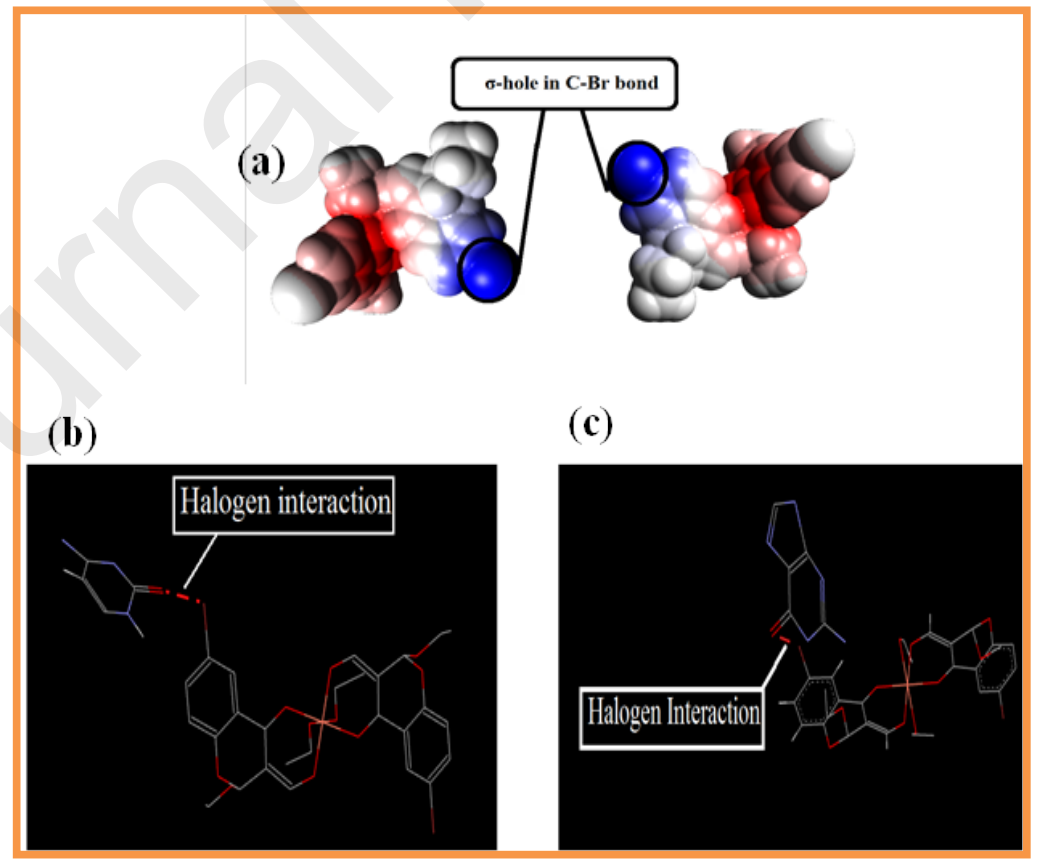

Fig. 3. Electrostatic potential surface depicting $\sigma$-hole in blue colour (a) in complex 2. Selected halogen $(\mathrm{Br}$ ) interactions of complex 2 with nucleobases, cytosine (a) and guanine (b). Hydrogen atoms have been omitted for clarity. 
Similarly, binding constant $(K)$ values of 1-3 were obtained from the Scatchard equation [37] with ct-DNA and the binding propensity further substantiated that complex $\mathbf{2}$ exhibited remarkable binding with ct-DNA as compared to complex 1 and $\mathbf{3}$ (Table 2).

The validation of binding mode of 1-3 was evaluated by performing competitive binding studies with ethidium bromide, EB. Ethidium bromide is a typical intercalator of ct-DNA possessing planar phenantridine ring by which it intercalates in between adjacent base pairs of the ct-DNA double helix, thus emitting intense florescence at ca.600 nm [38]. The enhanced florescence emission has been attributed to the formation EB-ct-DNA complex and may be quenched with the co-existence of motifs that intercalates ct-DNA equally or strongly than ethidium bromide. Upon addition of 1-3 to EB-ct-DNA system such that [complex]/[ct-DNA] $=1: 1$ to $5: 1$, the significant quenching of the band at $600 \mathrm{~nm}$ was observed (Fig. 4), resulting florescence emission was 32\% $33 \%$ of the initial EB-ct-DNA florescence intensity in case of complex $1 \& 2$ while it was 50\% for 3. These experimental results demonstrate that 1 \& $\mathbf{2}$ displaced EB from EB- ct-DNA system more efficiently than $\mathbf{3}$, thus implicating their non-covalent intercalative mode of binding with ct-DNA and groove binding interaction in case of 3. In an another florescence quenching experiment, Stern - Volmer constant, $K_{s v}$ values for 1-3 were calculated (equation 2) which depicted quenching of florescence, in the order $\mathbf{2}>\mathbf{1}>\mathbf{3}$ well corroborated with other binding studies ascertaining strong affinity of complexes $\mathbf{1}$ and $\mathbf{2}$ for ct-DNA as compared to $\mathbf{3}$. The calculated Stern-Volmer constant, $K_{s v}$ values for $\mathbf{1}, \mathbf{2}$ and $\mathbf{3}$ were found to be 5.04, 6.13 and 4.19, respectively.

$$
I_{0} / I=1+K_{\mathrm{sv}} \text { r }
$$



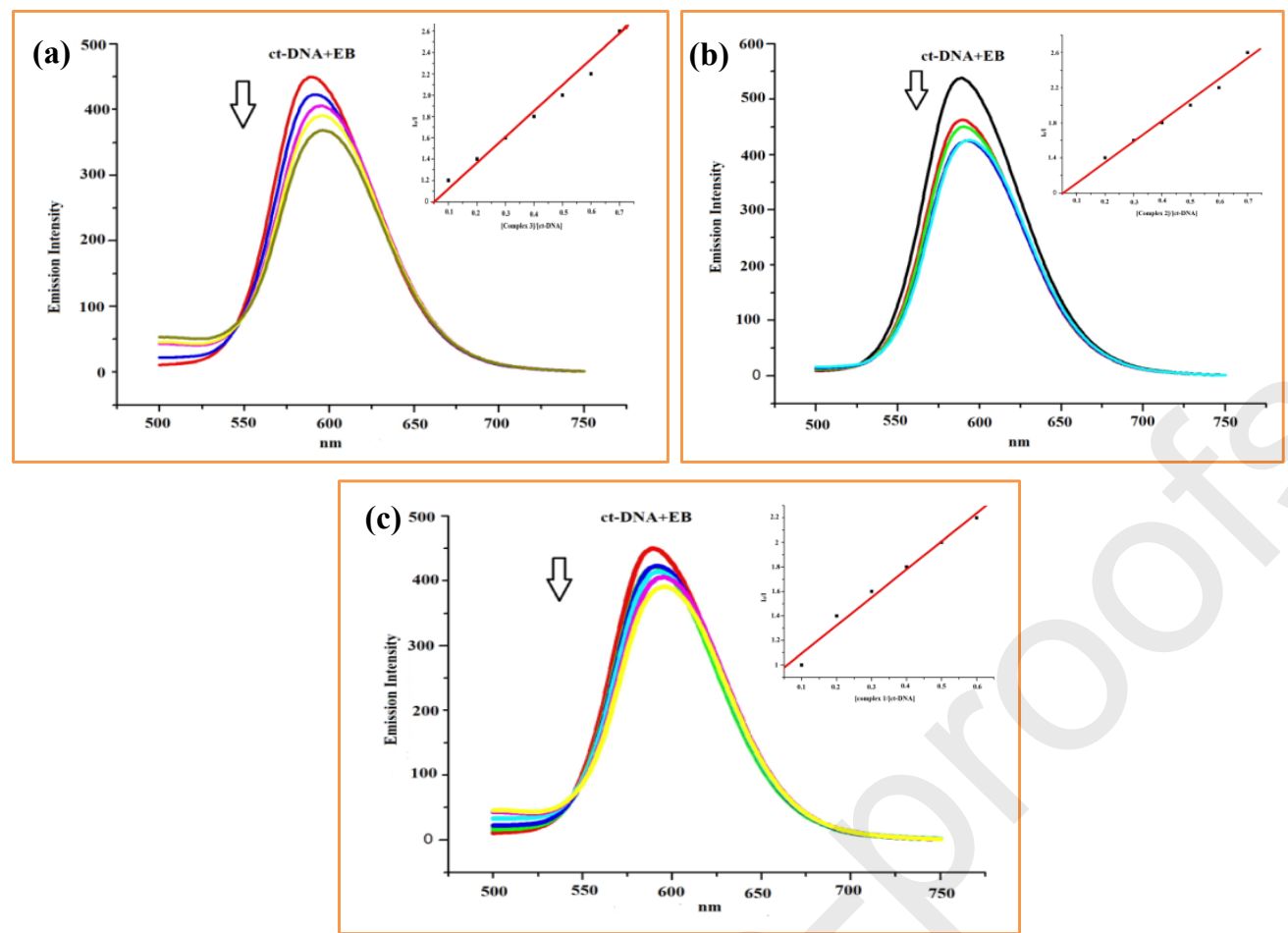

Fig. 4 Emission spectra of EB-ct-DNA in the absence and presence of complexes 1 (a), 2 (b) and 3 (c) in Tris- $\mathrm{HCl}$ buffer at $\mathrm{pH}$ 7.3. Arrow indicates change in intensity with increasing concentration of complexes $\mathbf{1}-\mathbf{3}$.

The liquid state X-band EPR spectra of complexes 1-3 were recorded in DMSO at LNT in the absence and presence of ct-DNA which revealed two $\mathrm{g}_{\|}$and two $\mathrm{g}_{\perp}$ signals (Fig. 5). Upon addition ct-DNA, EPR spectra of complex 2 exhibited weak signatures with minor shift in g-values, indicating the binding of complex 2 with ct-DNA [39,40]. However, the spectra of complex-ctDNA showed that the coordination number of the metal in 1-3 was not perturbed. Similar intensity pattern was observed in the complex- ct-DNA spectra of $\mathbf{1}$ and $\mathbf{3}$ (Fig. S3). 


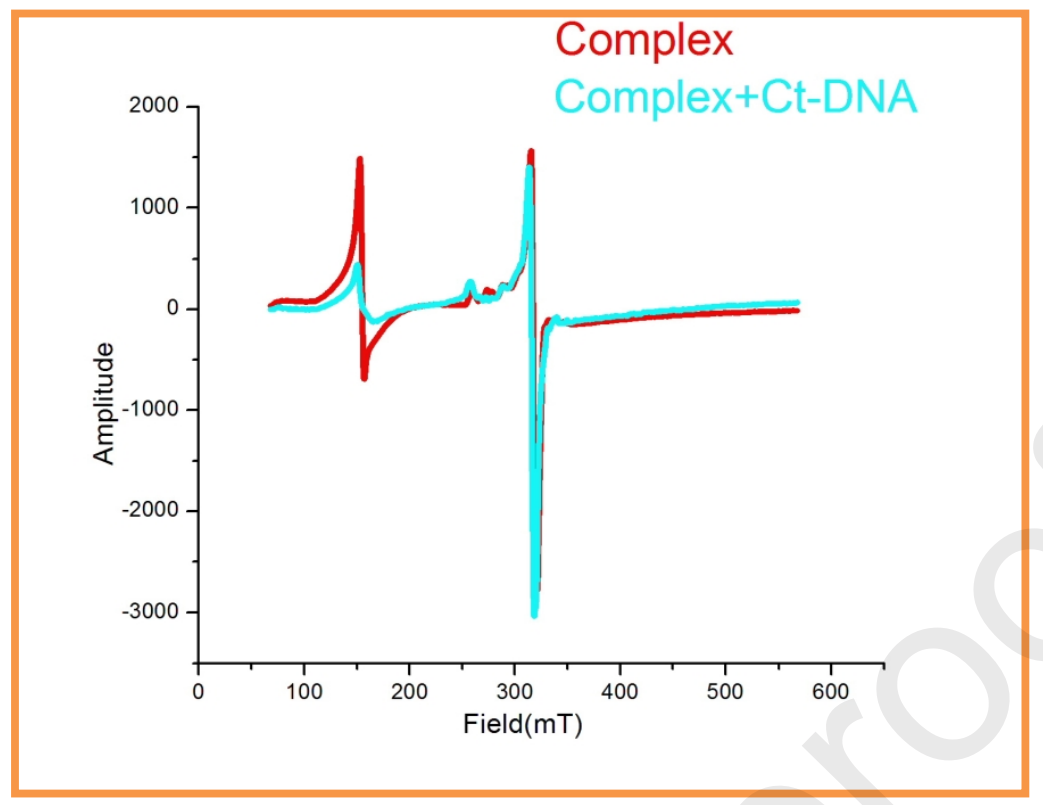

Fig. 5. X-band EPR (LNT) spectra of complex 2 (red), complex 2 + ct-DNA (blue).

Cyclic voltammetric studies of $\mathbf{1} \& \mathbf{2}$ in Tris- $\mathrm{HCl}$ buffer solution at a scan rate of 0.2 volts per second showed quasi-reversible one electron shuttle with $\mathrm{Cu}(\mathrm{II}) / \mathrm{Cu}(\mathrm{I})$ redox pairs and $\mathrm{E}_{1 / 2}=0.413$ volts and $\Delta \mathrm{E}_{\mathrm{P}}=0.193$ volts in case of 1 and $\mathrm{E}_{1 / 2}=0.442$ volts and $\Delta \mathrm{E}_{\mathrm{P}}=0.199$ volts in case of 2 , respectively. The ratio of anodic to cathodic $\left(\mathrm{I}_{\mathrm{a}} / \mathrm{I}_{\mathrm{c}}\right)$ peak current was found to be 0.49 . Upon interaction of $1 \& 2$ with ct-DNA, there was a positive potential shift in both $\Delta \mathrm{E}_{\mathrm{P}}=0.199$ volts and 0.213 volts; $\mathrm{E}_{1 / 2}=0.461$ and 0.471 volts in both 1 and 2 , respectively demonstrating that 1 \& 2 exhibited strong binding with ct-DNA (Fig.6). In the cyclic voltammogram of $1 \& \mathbf{2}$, a substantial decrease in current was observed possibly due to the slow diffusion of ct-DNA-Cu complex motif. The anodic to cathodic peak current $\left(\mathrm{I}_{\mathrm{a}} / \mathrm{I}_{\mathrm{c}}\right)$ of $1 \& 2$ also experienced a positive shift i.e., 0.53 and 0.56 , respectively. The greater shift of $\mathbf{2}$ as compared to $\mathbf{1}$ in the magnitude of $\Delta \mathrm{E}_{\mathrm{P}}, \mathrm{E}_{1 / 2}$ and $\left(\mathrm{I}_{\mathrm{a}} / \mathrm{I}_{\mathrm{c}}\right)$ suggests its strong binding affinity with ct-DNA [41]. 


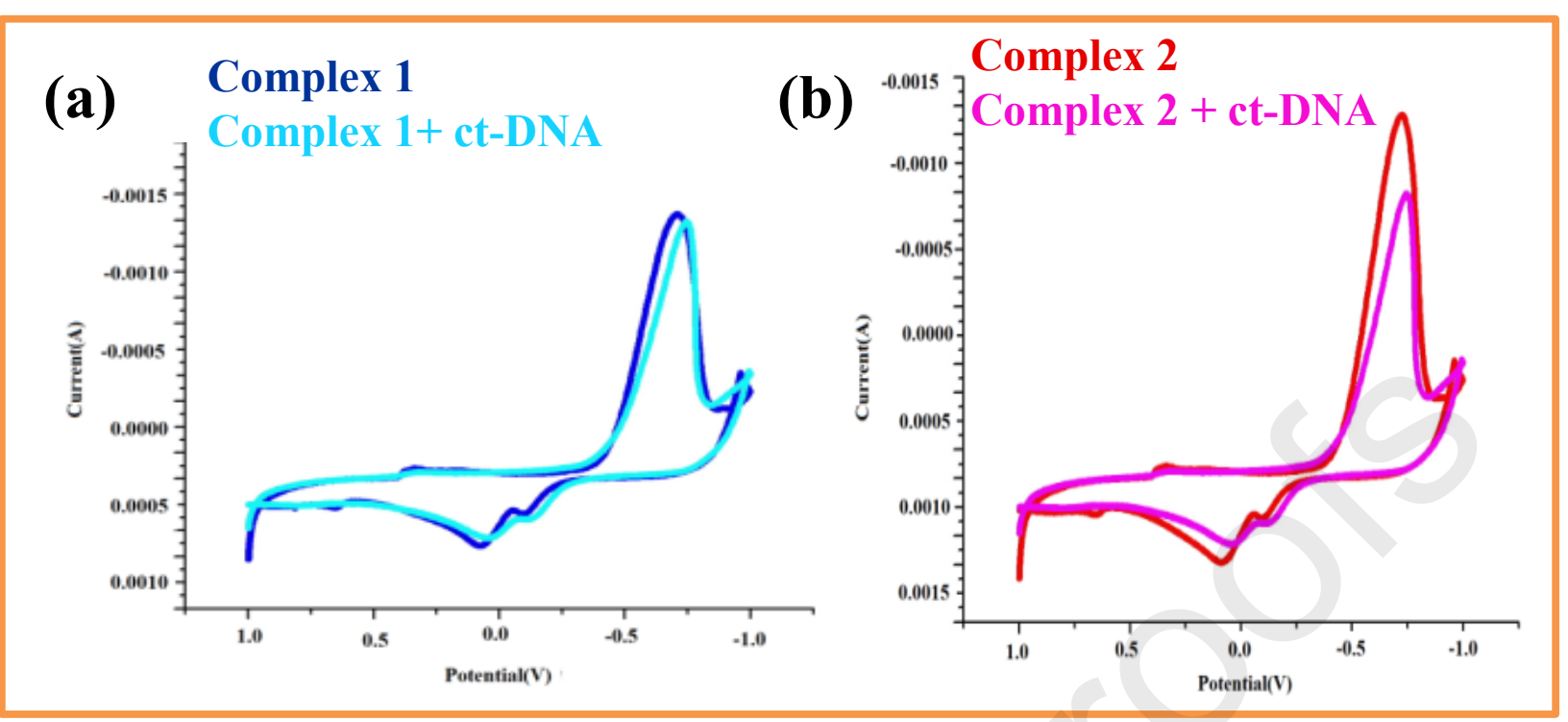

Fig. 6. Cyclic voltagrams $\left(1: 2 \mathrm{DMSO}\right.$ : Tris- $\mathrm{HCl}$ buffer solution, at $\left.25^{\circ} \mathrm{C}\right)$ of $\mathbf{1}$ and $\mathbf{2}$

Circular dichroism is an efficient and powerful optical technique used for the study of chiral biopolymers to analyse the stereochemical and conformational changes upon interaction with small molecules/metallo-drugs. In the CD spectrum of the characteristic right-handed B-form DNA, a positive peak at $276 \mathrm{~nm}$ is assigned to base stacking and a negative peak at $246 \mathrm{~nm}$ corresponds to the helicity of B-form DNA [42, 43]. The CD spectra of complexes 1-3 in presence of ct-DNA are depicted in Fig. 7. The less perturbations in the positive and negative bands upon addition of complex $\mathbf{3}$ are indicative of groove or electrostatic mode of binding whereas the enhancement of both positive and negative signatures with a slight shift in wavelength upon addition of $1 \& 2$ validate their intercalative mode of binding. 


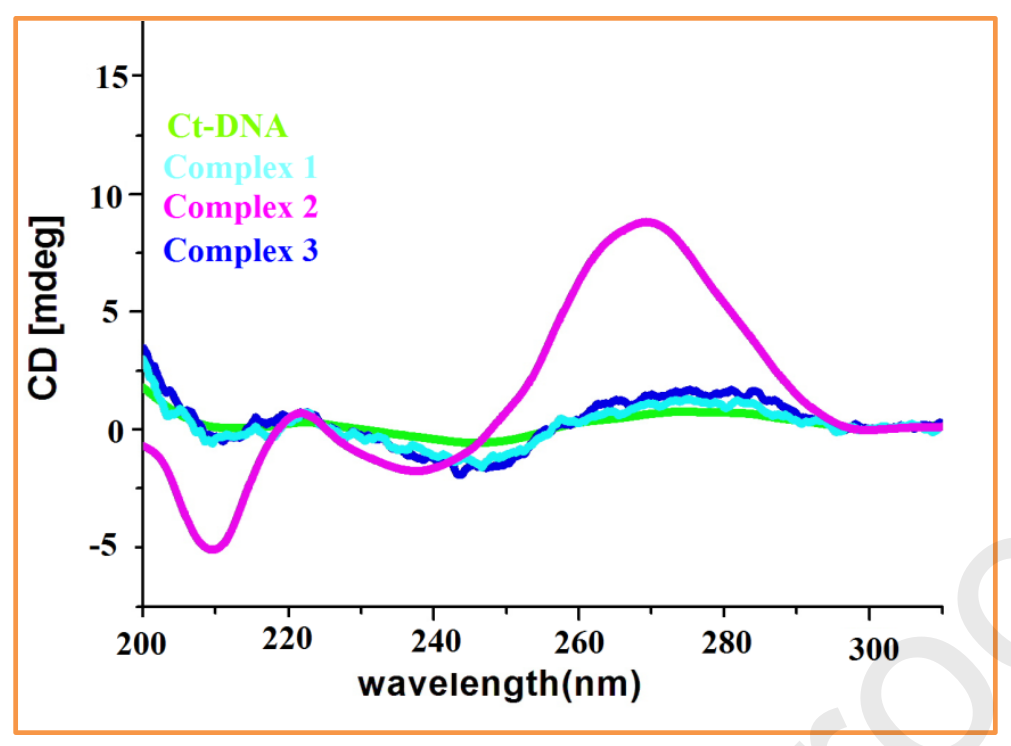

Fig. 7. CD spectra of complexes 1-3

\section{Morphological studies}

Due to the presence of various potential amenable binding sites in DNA viz., the phosphate group and electron donor atoms on nucleobases, metal ions carry out the dramatic condensation of DNA to a compact, rod like and toriodal structure, most commonly observed by electron microscopy. The condensation process has been attributed to diverse ionic interactions such as electrostatic and other forces viz., free energy of bending, mixing entropy, coulombic etc. [44]. The condensation or aggregation phenomena plays a critical role in many antitumor drugs. DNA condensation has become a dynamic useful technique as it can be used to transfer DNA containing genes of therapeutic interest from solution to target cells involving gene therapy $[45,46]$. Since DNA possess negative charge density due to nucleobases present in the major and minor grooves, positively charged metal ions can easily intercalate within these nucleobases, thus showing molecular recognition and in vivo modification of DNA in the condensed state. In this study, condensation of ct-DNA was achieved to examine the morphological changes under scanning electron microscope (SEM) by evaporating an equimolar mixture of $1-3$ in Tris- $\mathrm{HCl}$ buffer/ $50 \mathrm{mM}$ 
$\mathrm{NaCl}$ at $\mathrm{pH}=7.3$. The $\mathrm{SEM}$ micrographs of 1-3 showed single crystalline motifs in rod shapes (Fig. 8). On the contrary, the SEM micrographs of condensates of 1-3 with ct-DNA revealed the randomization and formation of globular structures, thus indicating substantial interaction of ctDNA with complexes similar to earlier reports on copper-DNA condensates $[47,48]$.

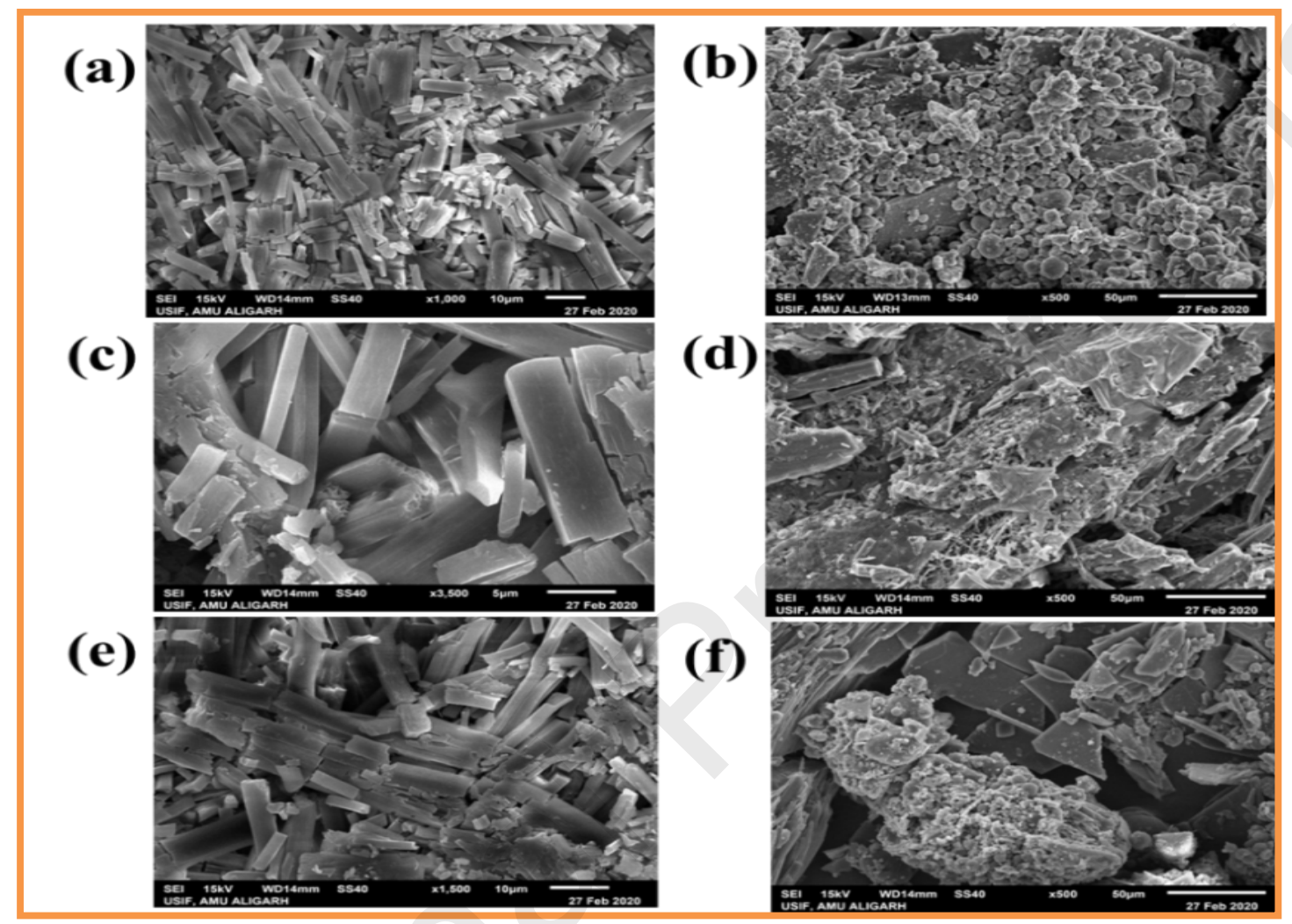

Fig. 8. SEM images of 1 (a), 2 (c), 3 (e) showing surface morphology upon condensation with ctDNA (b, d \& f, respectively).

\section{Molecular docking studies}

The molecular docking study of $\mathbf{1 - 3}$ was carried out with the d(CGCGAATTCGCG)2 (PDF ID : 1BNA) dodecamer sequence of DNA helix [49] to estimate the most probable binding affinity along with the sterically stable conformations (Fig.9). The binding energies for the best docked pose of complexes were quantified as $-333.98 \mathrm{~kJ} /$ mole for $\mathbf{1},-347.07 \mathrm{~kJ} / \mathrm{mole}$ and -294.72 $\mathrm{KJ} /$ mole for $\mathbf{2}$ and $\mathbf{3}$, respectively which revealed efficient DNA-drug interaction with the notably 
higher binding energy of complex 2 than the rest of complexes. Moreover, the results of docking implicated that complexes 1-3 fit snugly in the intercalative sites of DNA helix and moderately deep in adenine-cytosine rich region stabilized by hydrogen bonding, van der Waals interactions and hydrophobic contacts of aromatic chromone ring motif with the minor groove of ct-DNA; as the minor groove of DNA is considered to be lucrative target for many small molecules [50]. These interactions are considered to be the main driving force of the intercalative binding mode in addition to electrostatic interactions between the polarized bromine and the lone pair electrons of the nitrogen and oxygen atom of a neighboring nucleobases of DNA helix.

The greater binding energy of complex 2 was particularly supported by halogen donation via $\sigma$ hole of $\mathrm{C}-\mathrm{Br}$ covalent bond. This highly directional attraction between halogen atom (bromine in our case) and an electron donor nucleobase (adenine) helps in modulating the physicochemical properties of the molecular scaffolds; they affect the polarity and lipophilicity, which in turn could change membrane and blood brain barrier permeation of the molecule. Furthermore, the difficulty in metabolization of carbon-halogen, specifically $\mathrm{C}-\mathrm{Br}$ bond of $\mathbf{2}$ could prolong the lifetime of active motif [51]. The electron donor nucleobase to halogen interaction in complex $\mathbf{2}$ was found to be nitrogen atom of adenine wherein nitrogen atoms are seen to transfer its electron density directly into the $\sigma$-hole of $\mathrm{C}$-Br covalent bond, thus stabilizing DNA-drug interactions. Also the increasing stabilization was attributed to the aromatic character of nucleobase which allows them to act as electron donors via their $\Pi$ - electrons above and below their rings. 

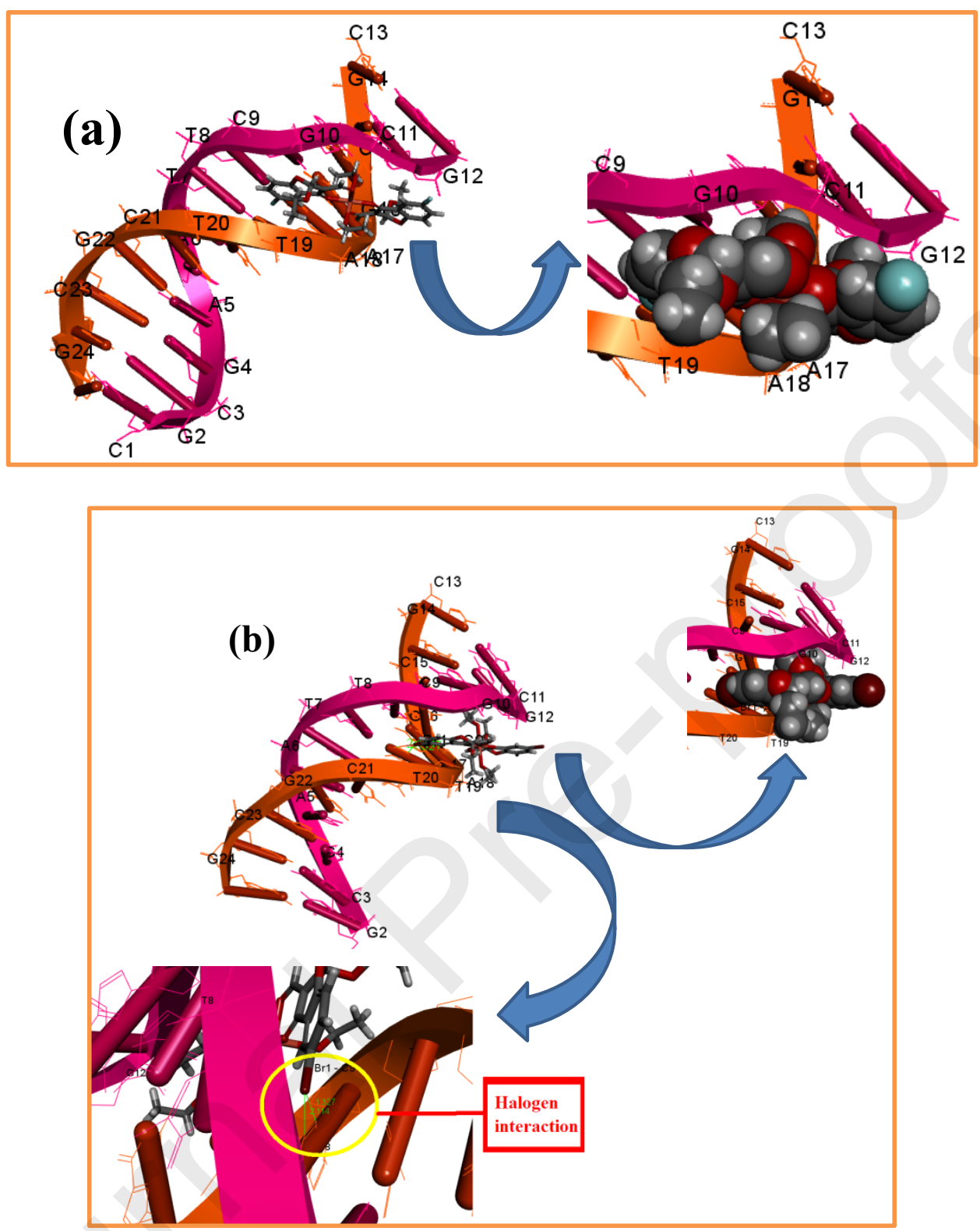


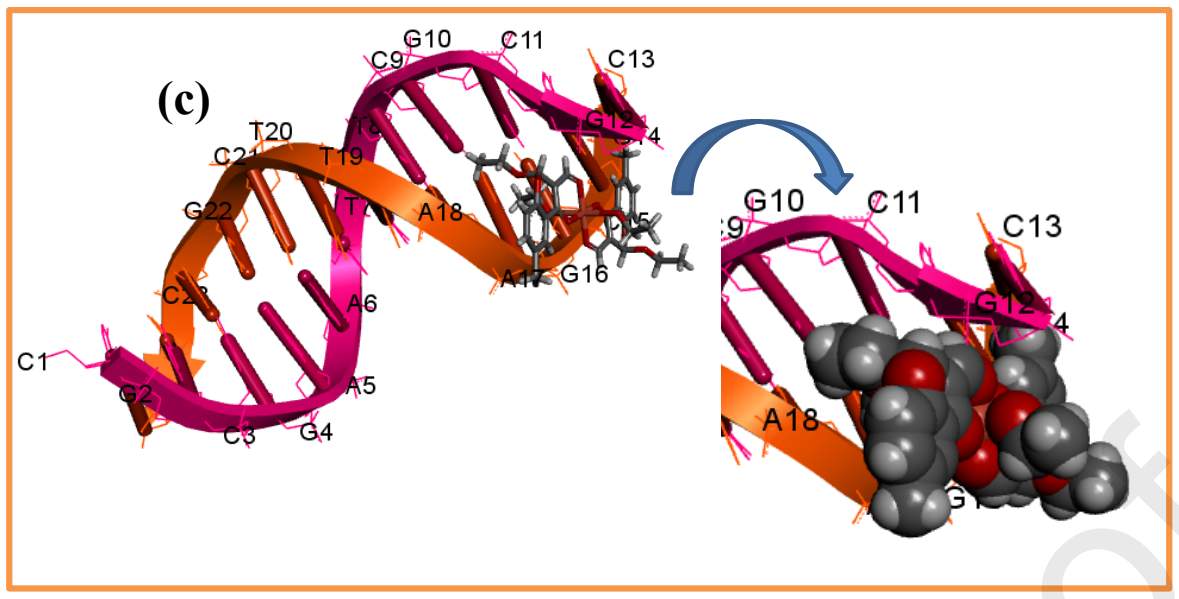

Fig. 9 Molecular docked model of complex 1 (a) complex 2 (b) and complex 3 (c) fitted into the $\mathrm{G}-\mathrm{C}$ region of the minor groove of the ct-DNA dodecamer duplex of sequence d(CGCGAATTCGCG) $)_{2}$, PDB ID: 1BNA.

\section{B3LYP/DFT Computational studies}

The electrostatic potential mapped structure was obtained to model the $\sigma$-hole region on the surface of $\mathrm{C}-\mathrm{Br}$ covalent bond which was shown by the emergence of electropositive region (Fig. 3a; blue) along the $\mathrm{C}$ - $\mathrm{Br}$ axis in complex $\mathbf{2}$, consistent with the presence of more polarizable $\mathrm{Br}^{-}$atom. This region is surrounded by an electroneutral ring (Fig.3a; white) and farther out, an electronegative region (Fig.3a; red). The presence of this $\sigma$-hole region indicates that complex is $\mathbf{2}$ more likely to serve as halogen bond donor to nucleobases via., its $\mathrm{Br}^{-}$atom, hence giving an indication of the specific and enhanced binding affinity of $\mathbf{2}$ as compared to $\mathbf{1}$ and $\mathbf{3}$ with ct-DNA.

Moreover, B3LYP/DFT calculations were performed on 1-3 to get an insight onto the frontier molecular orbitals and their energy gap values which help to shed light on the chemical reactivity, kinetic stability and electrical transport properties of a molecule. The HUMO-LUMO energy gap is also used to check bioactivity from intramolecular charge transfer and correlated with various biological aspects like antibacterial, antioxidant and DNA binding aspects $[52,53]$. The negative values of HOMO and LUMO indicates the stability of the complexes (Fig. 10). The higher value 
of $\mathrm{E}_{\mathrm{HOMO}}$ and lower values of $\mathrm{E}_{\mathrm{LUMO}}$ in $\mathbf{1 - 3}$ indicates their electron donating ability and electron accepting ability respectively. The orbital energy level analysis for complexes 1-3 shows that $\mathrm{E}_{\mathrm{HOMO}}$ values are $-5.605 \mathrm{eV},-5.566 \mathrm{eV}$ and $-5.337 \mathrm{eV}$, respectively while $\mathrm{E}_{\mathrm{LUMO}}$ values are -2.228 $\mathrm{eV},-2.262 \mathrm{eV}$ and $-1.880 \mathrm{eV}$, respectively. The lower value of $\mathrm{E}_{\mathrm{LUMO}}$ in complex 2 defines that it has more electron acceptance ability than $\mathbf{1}$ and $\mathbf{3}$; hence giving another evidence of the presence of $\sigma$-hole in $\mathrm{C}$-Br bond which supports the higher binding affinity of complex 2. Also the calculated $\Delta \mathrm{E}$ values of $\mathbf{1 - 3}$ are $3.337 \mathrm{eV}, 2.943 \mathrm{eV}$ and $3.457 \mathrm{eV}$, respectively. The lower value HOMO-LUMO energy gap in $\mathbf{2}$ suggested its greater stability as compared to $\mathbf{1}$ and $\mathbf{3}$.

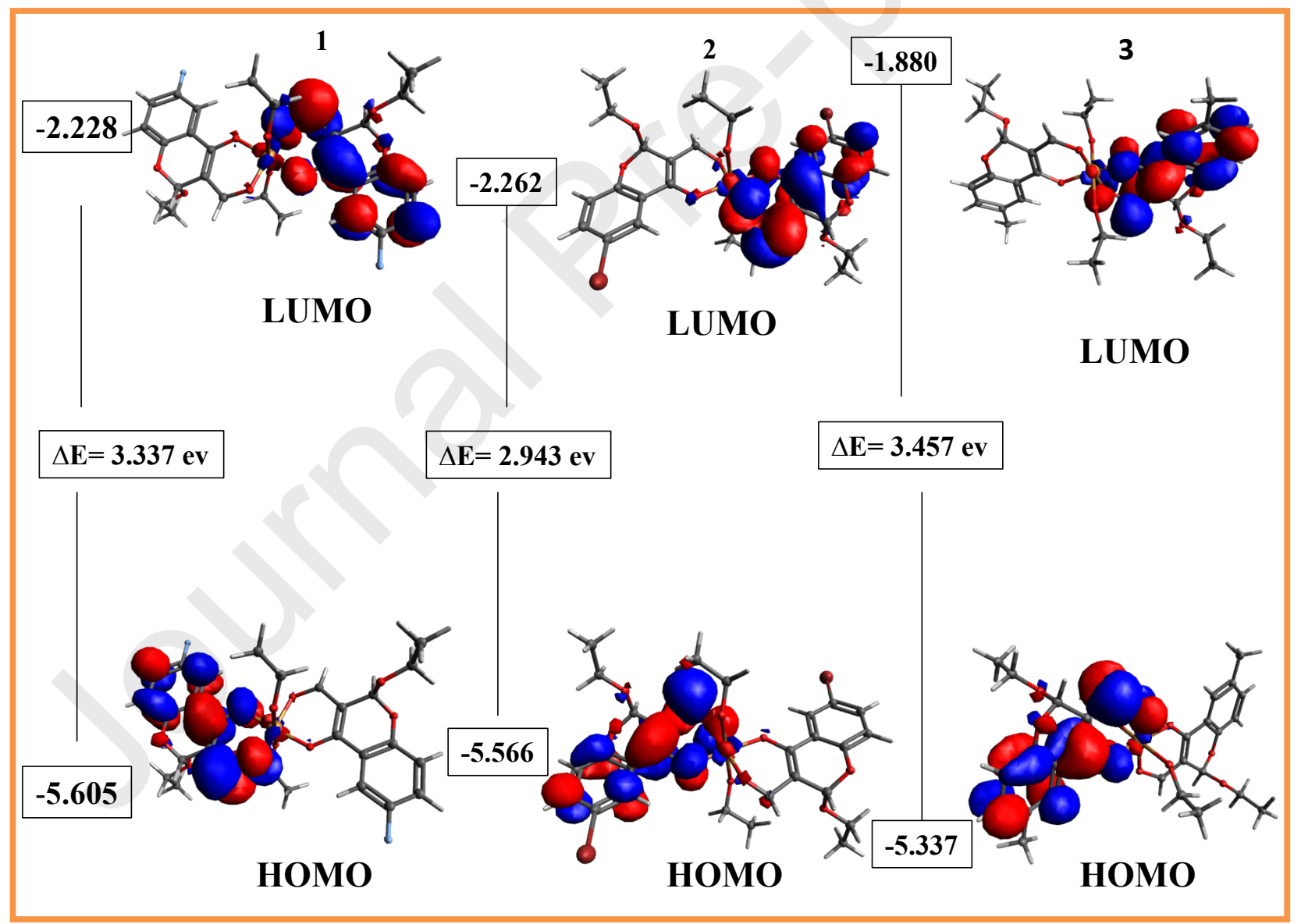

Fig. 10. Frontier molecular orbitals of complexes 1-3 using the B3LYP/DFT method. 


\section{In vitro cytotoxic activity}

The in vitro cytotoxic activity of complexes 1-3 was evaluated in terms of $\mathrm{LC}_{50}$ (the lethal concentration of the drug required to kill $50 \%$ of the cells) values by colorimetric $3-(4,5-$ dimethylthiazol-2-yl)-2,5-diphenyltetrazolium bromide (MTT) assay [54] on the panel of two cancer lines viz., human liver carcinoma (Huh-7), prostate cancer (DU-145) and one normal prostate epithelial (PNT1) cell lines. Complexes 1-3 $(2.5-10 \mu \mathrm{M})$ were treated for 48 hours which resulted in potential dose-dependent growth inhibition of both Huh-7 and DU-145 cancer cell lines irrespective of origin of the cells (Fig. 11), but complex $\mathbf{2}$ showed higher inhibition than $\mathbf{1}$ and 2 suggesting that the presence of $\mathrm{Br}^{-}$is lucrative in complex 2. Interestingly, no significant cell death was observed in the normal PNT1 cell lines upon treatment with complexes 1-3. 


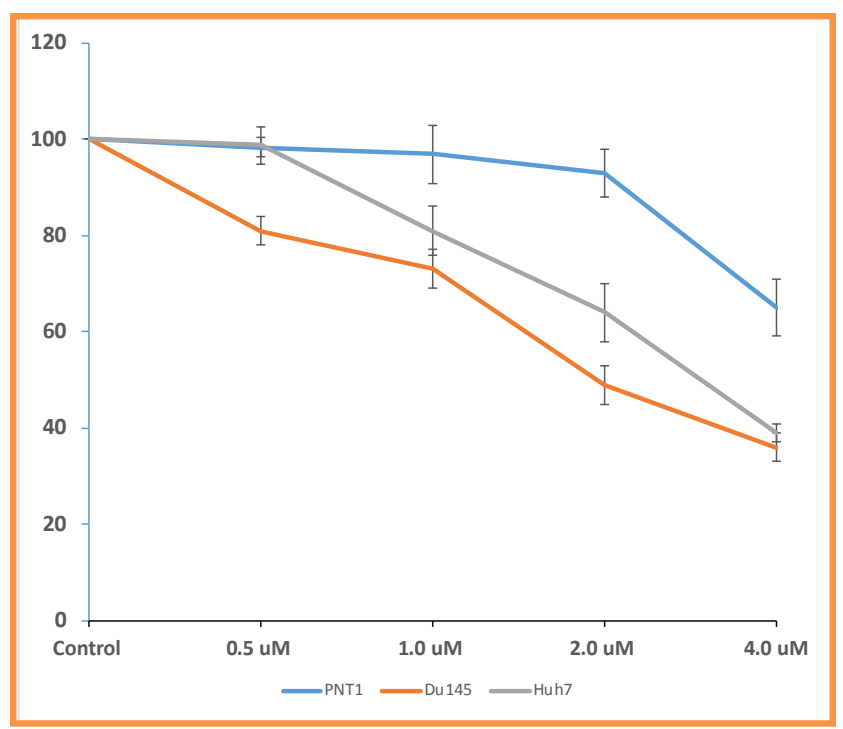

Complex 1

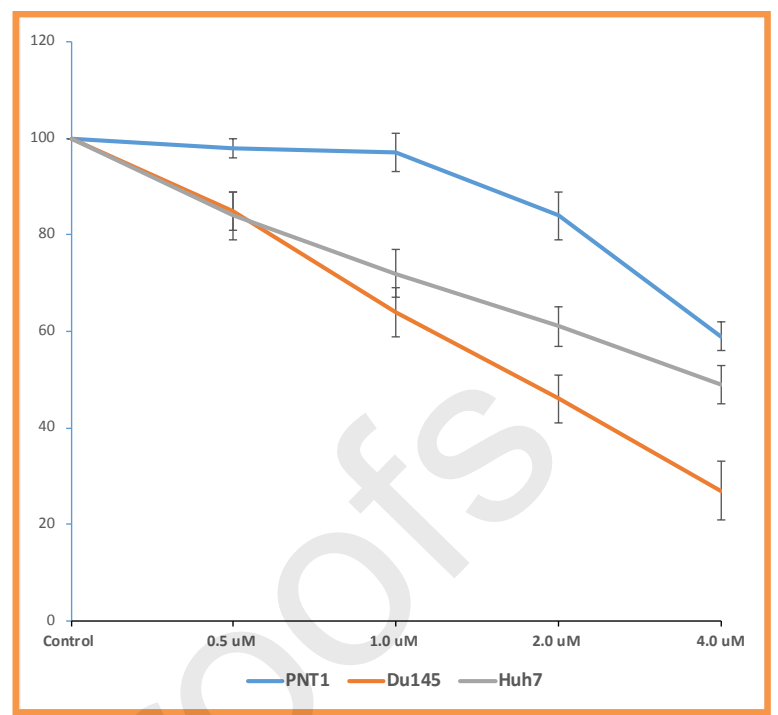

Complex 2

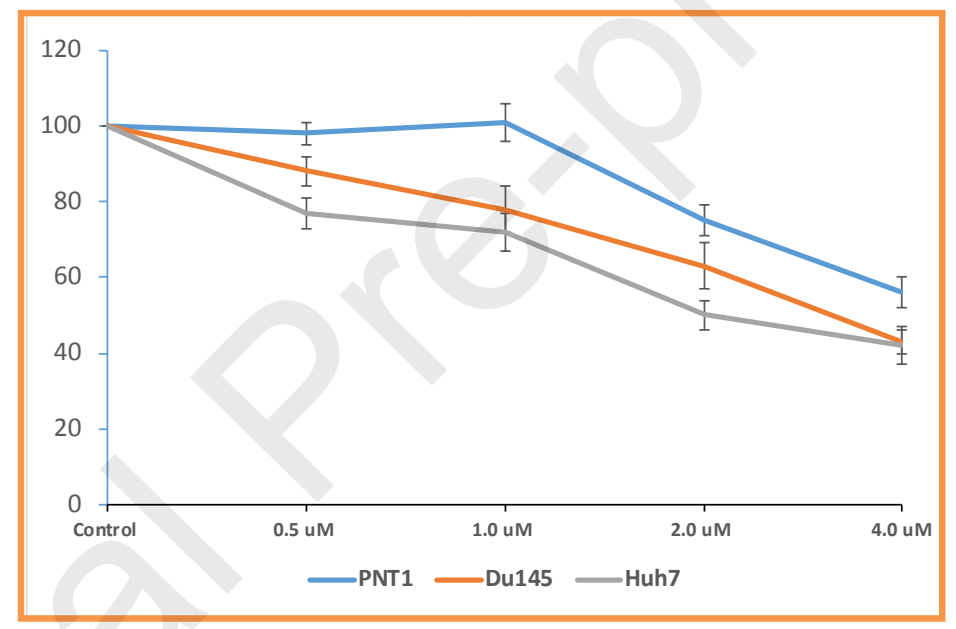

Complex 3

Fig. 11. Survival of tumor cells as a function of different concentrations of $1,2 \& 3$ determined by MTT test, after $48 \mathrm{~h}$ incubation.

\section{Cleavage activity}

The cleavage reaction of complexes 1-3 was monitored by agarose gel electrophoresis employing supercoiled pBR322 DNA as a substrate in a medium of $5 \mathrm{mM}$ Tris- $\mathrm{HCl} / 50 \mathrm{mM} \mathrm{NaCl}$ buffer at pH 7.2 under the influence of applied electric field. Upon gel electrophoresis of pBR322 DNA, the fastest migration results in the conversion of a supercoiled form (Form I) to a relaxed nicked form (Form II) and appearance of linearized form of DNA (Form III) in between the two, 
implicating efficient double stranded cleavage of the DNA [54]. Concentration-dependent (5-25 $\mu \mathrm{M}$ ) plasmid DNA cleavage experiments of 1-3 depicted the conversion of SC DNA (Form I) to NC DNA (Form II) and upon increasing the concentration of 1-3, there was the appearance of linearized form (Form III) which suggested double-stranded cleavage of plasmid DNA induced by 1-3, with the significantly higher cleavage exhibited by complex 2 at $20 \mu \mathrm{M}$ (Fig. 12 a and S4). Furthermore, the plasmid DNA cleavage activity of $\mathbf{2}$ was investigated to examine mechanistic pathway in the presence of additives viz., DMSO and EtOH as hydroxyl radical scavengers, $\mathrm{NaN}_{3}$ as singlet oxygen scavenger $\left({ }^{1} \mathrm{O}_{2}\right)$ and SOD as superoxide anion radical (Fig. $\left.12 \mathrm{~b}\right)$. During the reaction, it was ascertained that there was no significant quenching of plasmid DNA cleavage efficiency in presence of DMSO and $\mathrm{EtOH}$, hence excluding the possibility of hydrolytic cleavage pathway, involving diffusible hydroxyl radicals in the cleavage reaction. However, in the presence of SOD and $\mathrm{NaN}_{3}$ significant cleavage was observed, suggesting the oxidative cleavage pathway of complex 2 and demonstrated that ROS, singlet oxygen and superoxide anion radical could be responsible for cleavage activity [55] The further prediction of cleavage activity of complex 2 was discerned in presence of activators such as $\mathrm{H}_{2} \mathrm{O}_{2}$, glutathione (GSH), 3-mercaptopropionic acid (MPA) and methyl green (MG) which revealed the significant enhancement of DNA cleavage activity. The activity efficacy for complex 2 followed the order as $\mathrm{H}_{2} \mathrm{O}_{2}>\mathrm{GSH}>\mathrm{MPA}>\mathrm{MG}$. 


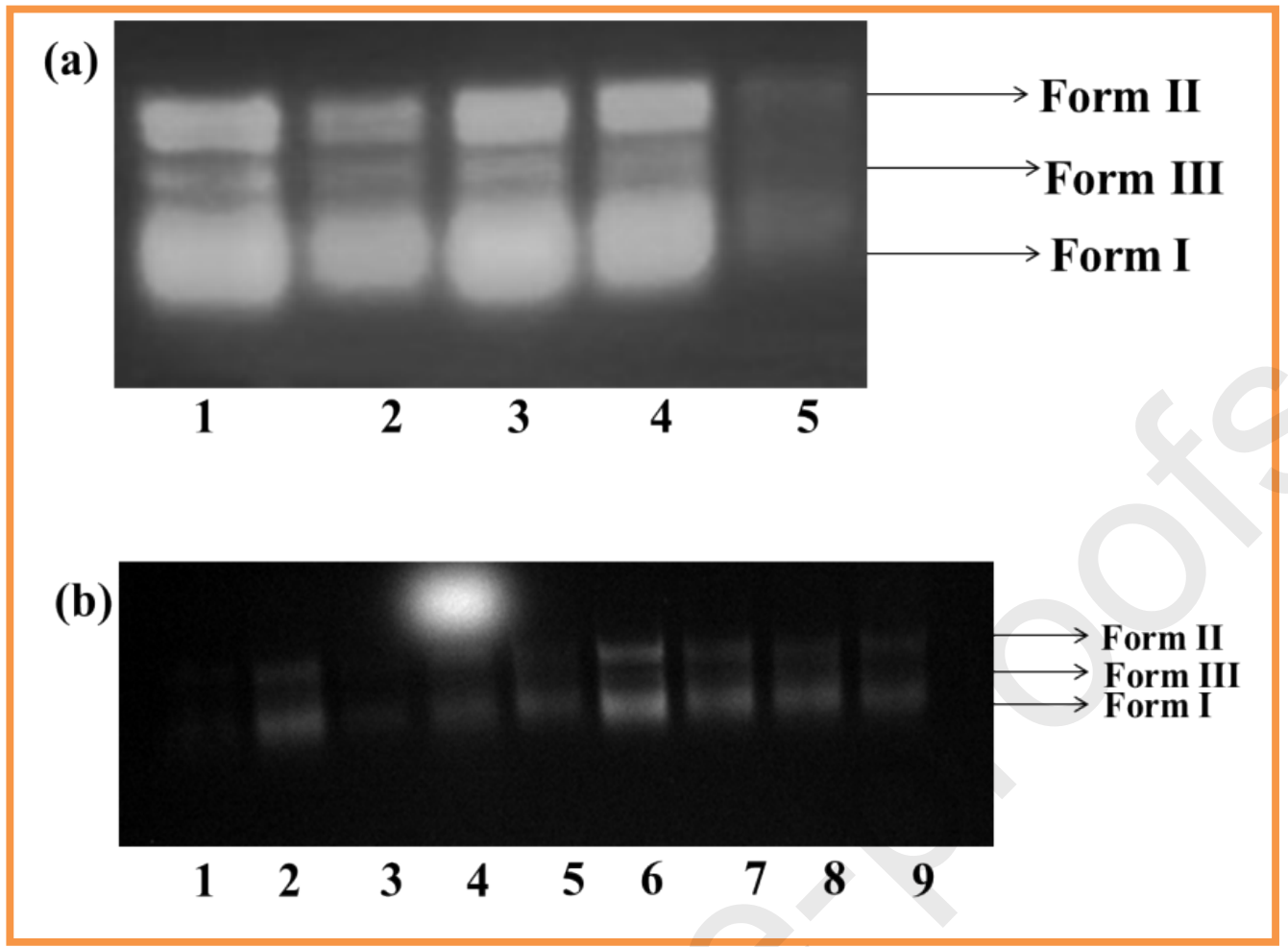

Fig. 12. Agarose gel electrophoresis demonstrating the cleavage of plasmid pBR322 DNA (300 ng) by complex 2 at $37^{\circ} \mathrm{C}$ in the presence of different exogenous agents. (a) Lane 1, DNA control; lane 2, DNA + $2(5 \mu \mathrm{M})$; lane 3, DNA + $2(10 \mu \mathrm{M})$; lane 4, DNA + $2(15 \mu \mathrm{M})$; lane 5, DNA + 2 $(20 \mu \mathrm{M})$; (b) lane 1, DNA control, lane 2, DNA + $2(20 \mu \mathrm{M})+\mathrm{H}_{2} \mathrm{O}_{2}(0.4 \mu \mathrm{M})$, lane 3, DNA +2 $(20 \mu \mathrm{M})+\mathrm{NaN}_{3}(0.4 \mu \mathrm{M})$, lane 4, DNA + $2(20 \mu \mathrm{M})+\mathrm{SOD}(0.4 \mu \mathrm{M})$, lane 5, DNA + $2(20 \mu \mathrm{M})$ + MPA $(0.4 \mu \mathrm{M})$, lane 6, DNA + $2(20 \mu \mathrm{M})+$ EtOH $(5 \mu \mathrm{L})$; lane 7, DNA + $2(20 \mu \mathrm{M})+$ DMSO $(5 \mu \mathrm{L})$; lane 8, DNA + $2(20 \mathrm{mM})+\mathrm{GSH}(20 \mu \mathrm{M})$; lane 9, DNA + $2(20 \mu \mathrm{M})+$ Methyl green $(0.4$ $\mu \mathrm{M})$.

\section{Experimental}

\section{Materials and instrumentation}

6-Methyl-3-Formylchromone, 6-Bromo-3-Formylchromone, 6-Chloro-3-Formylchromone were purchased from Sigma Aldrich. All the solvents reagents were of best commercial grade and were used without any further purification. Elemental analysis were employed on Carlo Erba Analyzer Model 1106. Fourier-transform infrared (FT-IR) spectrum were recorded on an Interspec 2020 and Spectrum Two (Perkin Elmer) FT-IR spectrometers. The EPR spectrum of copper complexes 1-3 were carried out on a Varian E 112 ESR spectrometer using X-band frequency $(9.5 \mathrm{GHz})$ at liquid 
nitrogen temperature. ESI-MS spectra were recorded on Micromass Quattro II triple quadrupole mass spectrometer. Electronic spectrum were recorded on UV-1700 PharmaSpec UV-vis spectrophotometer (Shimadzu) while as emission spectrum were assessed on RF-5301PC Spectrofluorophotometer (Shimadzu). CD spectra were procured on Jasco J-815-CD spectropolarimeter. All experiments involving the interaction of complexes 1-3 with ct-DNA were carried out in aerated buffer $(5 \mathrm{mM}$ Tris- $\mathrm{HCl}, 50 \mathrm{mM} \mathrm{NaCl}, \mathrm{pH}=7.3)$. The concentrations per base pairs for ct-DNA were obtained spectrophotometrically by assuming $\epsilon_{260} \mathrm{~nm}$ values to be $6600 \mathrm{M}^{-1} \mathrm{~cm}^{-1}$, respectively. Cleavage experiments were performed with the help of Axygen electrophoresis supported by a Genei power supply with a potential range of 50-500 V, visualized and photographed by a Vilber-INFINITY gel documentation system.

\section{Synthesis of Complexes 1-3}

\section{Synthesis of complex 1}

Complex 1 was synthesized by stirring ethanolic solutions of copper (II) nitrate trihydrate $(0.241$ $\mathrm{g}, 1 \mathrm{mmol})$ with 6-fluoro-3-formylchromone $(.348 \mathrm{~g}, 2 \mathrm{mmol})$ in the molar ratio 2:1 under reflux conditions for $5 \mathrm{~h}$. The resulting solution was filtered and allowed to evaporate slowly at room temperature. Green coloured crystals suitable for single X-ray crystallography were obtained after 2-3 days of slow evaporation of the reaction mixture which were found to be quite stable towards air and soluble in organic solvents such as EtOH, acetone, THF, DMF and DMSO. Yield: 78\%, melting point: $214^{\circ} \mathrm{C} . \mathrm{CCDC}$ no. 1970411 . Elemental analysis calculated for $\mathrm{C}_{28} \mathrm{H}_{32} \mathrm{CuF}_{2} \mathrm{O}_{10}$ : C, 53.37; H, 5.12. Found: C, 53.45; H, 5.15. FT-IR (KBr, v $\left.v_{\max } / \mathrm{cm}^{-1}\right): 3069 v(-\mathrm{C}-\mathrm{H}), 1614 v(-\mathrm{C}=\mathrm{O})$, 1060 v(-C-O), 1263 v(-C-F). UV-vis $\left(1 \times 10^{-3}\right.$ M, DMSO, $\left.\lambda_{\max }, \mathrm{nm}\right): 282,310,341$ and 620.

\section{Synthesis of complex 2}


Complex 2 was synthesized by stirring ethanolic solutions of copper (II) nitrate trihydrate (0.241 g, $1 \mathrm{mmol}$ ) with 6-bromo-3-formylchromone (.506 $\mathrm{g}, 2 \mathrm{mmol})$ in the molar ratio 2:1 under reflux conditions for $4 \mathrm{~h}$. The resulting solution was filtered and allowed to evaporate slowly at room temperature. Very fine green coloured crystals suitable for single X-ray crystallography were obtained after 3-4 days of slow evaporation of the reaction mixture which were found to be quite stable towards air and soluble in organic solvents such as EtOH, THF, DMF and DMSO. Yield: 76\%, melting point: $209{ }^{\circ} \mathrm{C}$. CCDC no. 1987454. Elemental analysis calculated for $\mathrm{C}_{28} \mathrm{H}_{32} \mathrm{Br}_{2} \mathrm{CuO}_{10}$ : C, 44.73; H, 4.29. Found: C, 44.78; H, 4.35. FT-IR (KBr, v $\left.{ }_{\max } / \mathrm{cm}^{-1}\right)$ : 3089 v(-CH), 1656 v(-C=O), 1045 v(-C-O), 535 v(-C-Br). UV-vis $\left(1 \times 10^{-3} \mathrm{M}, \mathrm{DMSO}, \lambda_{\max }, \mathrm{nm}\right): 296,315$, 380 and 660.

\section{Synthesis of complex 3}

Complex 3 was synthesized by stirring ethanolic solutions of copper (II) nitrate trihydrate (0.241 $\mathrm{g}, 1 \mathrm{mmol})$ with 6-methyl-3-formylchromone $(.376 \mathrm{~g}, 2 \mathrm{mmol})$ in the molar ratio 2:1 under reflux

conditions for $6 \mathrm{~h}$. The resulting solution was filtered and allowed to evaporate slowly at room temperature. Green crystals suitable for single X-ray crystallography were obtained after 5-6 days of slow evaporation of the reaction mixture which were found to be quite stable towards air and soluble in organic solvents such as EtOH, THF, DMF and DMSO. Yield: 83 \%, melting point: 223 ${ }^{\circ} \mathrm{C} . \mathrm{CCDC}$ no. 1969139 . Elemental analysis calculated for $\mathrm{C}_{30} \mathrm{H}_{38} \mathrm{CuO}_{10}$ : C, 57.91; H, 6.16. Found: C, 57.96; H 6.23. FT-IR (KBr, v max $\left./ \mathrm{cm}^{-1}\right)$ : 2974 v(-C-H), 1606 v(-C=O), 1060 v(-C-O). UV-vis $\left(1 \times 10^{-3}\right.$ M, DMSO, $\left.\lambda_{\max }, \mathrm{nm}\right): 298,335,357$ and 698 .

\section{Molecular docking studies}

The molecular docking studies were performed by employing HEX 8.0 software. [56, 57] The BDNA dodecamer d(CGCGAATTCGCG) 2 (PDB ID : 1BNA) crystal structure was downloaded 
from the http://www.rcsb.org./pdb (protein data bank). Before employing docking experiments, the structure of complexes 1-3 were converted into PDB format and the visualization was done by using Discovery Studio molecular graphics program.

\section{Computational studies}

Single-point density functional theory (DFT) calculations and geometry optimization were carried out by the using hybrid B3LYP functional. The optimized structure was further calculated using def2-TZVP basis set for all atoms to calculate the HOMO and LUMO energies.

The def2-TZV/J main, and def2-SVP/J auxiliary, Coulomb fitting basis set were used as implemented in the ORCA, to accelerate the calculations.

\section{In vitro binding and cleavage experiments}

The DNA binding experiments were performed in Tris- $\mathrm{HCl} / \mathrm{NaCl}(5: 50 \mathrm{mM})$ buffer at $\mathrm{pH} 7.3$ by employing absorption spectroscopy, emission spectroscopy, cyclic voltammetry and circular dichroism following previously used standard methods adopted by our laboratory [58,59] The cleavage experiments of complexes 1-3 were carried out using agarose gel electrophoresis in Tris$\mathrm{HCl} / \mathrm{NaCl}$ (5:50 mM) buffer at pH 7.3 using supercoiled pBR322 DNA (300 ng).

\section{Cytotoxic studies}

In vitro antitumor screening of complexes 1-3 was performed on human cancer lines of two different histological origin viz., Du145 (prostate) and Huh7 (Liver). The effect of complexes 1-3 on cell viability was determined by MTT assay. Briefly, cells were seeded in 96-well dishes at a density of $3.5 \times 10^{3}$ cells per well. Cells were allowed to attach for $24 \mathrm{~h}$ before incubation with fresh medium containing either complex 1/2/3 (2.5-10.0 mM) for $48 \mathrm{~h}$. After incubation for $48 \mathrm{~h}$ at $37^{\circ} \mathrm{C}$, MTT assay was performed as described previously [60].

\section{Description of X-ray crystal structures}


Single crystal X-ray structural studies of complexes 1-3 were performed on a D8 VENTURE Bruker AXS diffractometer, employing graphite-mono-chromated Mo-K $\alpha$ radiation generated from a fine-focus sealed tube $\left(\lambda=0.71073{ }^{\circ} \mathrm{A}\right)$ at $150 \mathrm{~K}$. The structure was solved by dual-space algorithm using the SHELXT program and further refined with full-matrix least-square methods based on F2 (SHELXL). All non-hydrogen atoms were refined with anisotropic atomic displacement parameters. $\mathrm{H}$ atoms were finally included in their calculated position. The drawing of the complex was realized with PLATON [61] A summary of selected crystallographic information for complexes $\mathbf{1 - 3}$ is given in Table 2.

Table 2 Crystallographic data for complexes 1-3.

\begin{tabular}{|c|c|c|c|}
\hline Parameters & 1 & 2 & 3 \\
\hline CCDC & 1970411 & 1987454 & 1969139 \\
\hline Formula & $\mathrm{C}_{28} \mathrm{H}_{32} \mathrm{CuF}_{2} \mathrm{O}_{10}$ & $\mathrm{C}_{28} \mathrm{H}_{32} \mathrm{Br}_{2} \mathrm{CuO}_{10}$ & $\mathrm{C}_{30} \mathrm{H}_{38} \mathrm{CuO}_{10}$ \\
\hline Fw $\left(\mathrm{g} \mathrm{mol}^{-1}\right)$ & 630.07 & 751.89 & 622.14 \\
\hline Crystal system & Monoclinic & Triclinic & Triclinic \\
\hline Space group & $P 21 / n$ & $P-1$ & $P-1$ \\
\hline a (§̊) & $9.9291(4) \AA$ & $5.1134(5)$ & $5.1349(4)$ \\
\hline b (Å) & $5.1435(2) \AA$ & $9.7980(9)$ & $11.6066(9)$ \\
\hline c (Å) & $27.7256(10) \AA$ & $14.9650(14)$ & $12.9630(11)$ \\
\hline$\alpha(\operatorname{deg})$ & $90^{\circ}$ & $85.415(3)^{\circ}$ & $105.733(3)^{\circ}$ \\
\hline$\beta(\operatorname{deg})$ & $98.1990(10)^{\circ}$ & $83.430(3)^{\circ}$ & $97.741(3)^{\circ}$ \\
\hline$\gamma(\operatorname{deg})$ & $90^{\circ}$ & $89.988(4)^{\circ}$ & $90.384(3)^{\circ}$ \\
\hline $\mathbf{U}\left(\AA^{3}\right)$ & $1401.48(9)$ & $742.43(12)$ & $736.10(10)$ \\
\hline$\rho_{\text {calc }}\left(\mathrm{g} / \mathrm{cm}^{3}\right)$ & 1.493 & 1.682 & 1.403 \\
\hline
\end{tabular}




$\begin{array}{lllc}\boldsymbol{\mu}\left(\mathbf{m m}^{-1}\right) & 0.849 & 3.481 & 0.798 \\ \text { Temp (K) } & 150 & 150 & 150 \\ \text { Measured refIns } & 10339 & 3367 & 13894 \\ \text { Indep reflns } & 3218 & 3367 & 3385 \\ \mathbf{G o F}^{\mathbf{a}} & 1.077 & 1.161 & 1.088 \\ \mathbf{R}^{\mathbf{b}}[\mathbf{I}>\mathbf{2} \mathbf{\sigma}(\mathbf{I})] & 0.0337 & 0.0583 & 0.0266 \\ \mathbf{W R}_{\mathbf{2}}^{\mathbf{b}} \text { (all data) } & 0.0879 & 0.1267 & 0.0663\end{array}$

${ }^{\mathrm{a}} \mathrm{GoF}$ is defined as $\left\{\Sigma\left[\mathrm{w}\left(\mathrm{F}_{0}{ }^{2}-\mathrm{F}_{\mathrm{c}}{ }^{2}\right)\right] /(\mathrm{n}-\mathrm{P})\right\}^{1 / 2}$ where $\mathrm{n}$ is the number of data and $\mathrm{p}$ is the number of parameters. ${ }^{b} \mathrm{R}=\left\{\Sigma|| \mathrm{F}_{0}|-| \mathrm{F}_{\mathrm{c}}|/ \Sigma| \mathrm{F}_{0} \mid, \mathrm{wR}^{2}=\left\{\Sigma \mathrm{w}\left(\mathrm{F}_{0}{ }^{2}-\mathrm{F}_{\mathrm{c}}{ }^{2}\right)^{2} / \Sigma \mathrm{w}\left(\mathrm{F}_{0}^{2}\right)^{2}\right\}^{1 / 2}\right.$.

\section{Conclusions}

New $\mathrm{Cu}$ (II) drug entities 1-3 derived from substituted $\left(\mathrm{F}^{-}, \mathrm{Br}^{-},-\mathrm{CH}_{3}\right)$ bioactive chromone pharmacophore were synthesized as antitumor chemotherapeutic agents. The complexes 1-3 were thoroughly characterized by various spectroscopic techniques (IR, UV-vis, EPR and ESI-MS) and single X-ray crystallography. Interaction of complexes 1-3 with ct-DNA was carried out employing UV-vis, fluorescence, cyclic voltammetry, EPR and circular dichroism techniques. The corroborative results of these experiments with ct-DNA showed higher binding propensity of complex 2 as compared to complexes $1 \& 3$. It was observed that complex 2 facilitates strong halogen bonding interaction via, $\mathrm{Br}$ and stability of halogen bond was rationalized by the presence of sigma hole region as observed by gas phase B3LYP computational DFT studies. Moreover, the cleavage activity of complexes 1-3 with pBR322 DNA suggested double strand cleaving ability of the complexes and the mechanism was mediated by oxidative cleavage pathway involving SOD and $\mathrm{NaN}_{3}$. In vitro cytotoxic activity of complexes 1-3 was carried out on a panel of two human cancer cell lines by MTT assay and the growth curve data revealed greater potency of complex 2 
towards human liver carcinoma (Huh-7) and prostate cancer (DU-145) cell lines than the other two complexes $1 \& 3$.

\section{Conflicts of interest}

There are no conflicts to declare.

\section{Acknowledgements}

The authors are thankful to SAIF, CIL, Panjab University, and Chandigarh for providing elemental analysis facility. The authors also acknowledge the University Sophisticated Instrumentation Facility (USIF), Aligarh Muslim University, for carrying out the SEM studies. The author (Salman Khursheed) sincerely expresses his gratitude to University Grants Commission (UGC), New Delhi, for providing the fellowship through UGC-assisted DRS-SAP, DST-FIST and DST- PURSE Programme.

\section{References}

[1] C Santini, M. Pellei, V Gandin, M Porchia, F. Tisato, C. Marzano, Advances in Copper Complexes as Anticancer Agents, Chem. Rev. (2014)114, 1, 815-862 .

[2] N. Muhammad, Z. Guo, Metal-based anticancer chemotherapeutic agents. Curr. Opinion Chem. Biol. 19 (2014) 144-153.

[3] (a) F. Tisato, C. Marzano, M. Porchia, M. Pellei, C. Santini, Copper in diseases and treatments, and copper-based anticancer strategies. Med. Res. Rev. 30 (2010) 708749; (b) A. Kellett, Z. Molphy, V. McKee, C. Slator, Recent advances in anticancer copper compounds. Metal-based Anticancer Agents, 14 (2019) 91-119.

[4] A. Vessieres, S. M. Meier-Menches, \& A. Casini (Eds.), Recent Advances in Anticancer Copper Compounds. Metal-based Anticancer Agents , RSC Metallobiology 14 (2019) 91-119 
[5] V. Uma, M. Kanthimathi ,T. Weyhermuller, B. U. Nair, Oxidative DNA cleavage mediated by a new copper(II) terpyridine complex: Crystal structure and DNA binding studies, journal of Inorganic Biochemistry, 99 (2006) 2299-307

[6] C. K. Sen, S. Khanna, M. Venojarvi, P. Trikha, E. C. Ellison, T. K. Hunt, S. Roy, Copper-induced vascular endothelial growth factor expression and wound healing. Am. J. Physiol.: Heart Circ. Physiol. 282 (2002) H1821-H1827.

[7] A. Nasulewicz, A. Mazur and A. Opolski, Role of copper in tumour angiogenesisclinical implications. J. Trace Elem. Med. Bio. 180 (2004) 1-8.

[8] M. Moriguchi, T. Nakajima, H. Kimura, T. Watanabe, H. Takashima, Y. Mitsumoto, T. Katagishi, T. Okanoue, K. Kagawa, The copper chelator trientine has an antiangiogenic effect against hepatocellular carcinoma, possibly through inhibition of interleukin-8 production. Int. J. Cancer 102 (2002) 445-452.

[9] (a) J. Folkman, Tumor angiogenesis: therapeutic implications. N. Engl. J. Med. 285 (1971) 1182-1186; (b) J. Folkman, Angiogenesis. Annu. Rev. Med 57 ( 2006) 1-18.

[10] A. Gupte, R. J Mumper, Elevated copper and oxidative stress in cancer cells as a target for cancer treatment. Cancer Treat. Rev. 35 (2009) 32- 46.

[11] A. Gaspar, M. J. Matos, J. Garrido, E. Uriarte, F. Borges, Chromone: a valid scaffold in medicinal chemistry. Chem. Rev. 114 (2014) 4960-4992. J. Reis, A. Gaspar, N. Milhazes, F. Borges, Chromone as a Privileged Scaffold in Drug Discovery: Recent Advances: Miniperspective. J. Med. Chem. 60 (2017) 7941-7957.

[12] R. S. Keri, S. Budagumpi, R. K. Pai, R. G. Balakrishna, Chromones as a privileged scaffold in drug discovery: A review. Eur. J. Med. Chem., 78 (2014) 340-374. 
[13] C. Zwergel, S. Valente, A. Salvato, Z. Xu, O. Talhi, A. Mai, A. Silva, L. Altucci, G. Kirsch, Novel benzofuran-chromone and-coumarin derivatives: synthesis and biological activity in K562 human leukemia cells. Med. Chem. Comm. 4 (2013) $1571-1579$.

[14] A. Gaspar, N. Milhazes, L. Santana, E. Uriarte, F. Borges, M.J. Matos, Oxidative stress and neurodegenerative diseases: looking for a therapeutic solution inspired on benzopyran chemistry. Curr. Top. Med. Chem. 15 (2015) 432-445.

[15] J.E. Philip, M. Shahid, M.P. Kurup, M.P. Velayudhan, Metal based biologically active compounds: Design, synthesis, DNA binding and antidiabetic activity of 6methyl-3-formyl chromone derived hydrazones and their metal (II) complexes. J. Photochem. Photobiol. B 175 (2017) 178-191.

[16] O. Talhi, M. Schnekenburger, J. Panning, D. G. Pinto, J.A .Fernandes, F.AAlmeida Paz, C. Jacob,M. Diederich, A.M. Silva, Bis(4-hydroxy-2H-chromen-2-one): synthesis and effects on leukemic cell lines proliferation and NF-kappa B regulation. Bioorg. Med. Chem. 22 ( 2014) 3008-3015.

[17] L. -J. Tang, X. Chen, Y. -N. Sun, J. Ye, J. Lu, Y. Han, X. Jiang, C. C. Cheng, C. C. He, P. -H. Qiu, X. -K. Li, Synthesis and biological studies of 4', 7, 8-trihydroxyisoflavone metal complexes. J. Inorg. Biochem. 105 (2011) 1623-1629.

[18] G. Kalaiarasi, S. R. J. Rajkumar, S. Dharani, V. M. Lynch, R. Prabhakaran, Synthesis, spectral characterization and biological evaluation of some copper(II) complexes containing 4-oxo-4H-chromene-3-carbaldehyde-4(N)-substituted thiosemicarbazones. Inorg. Chim. Acta, 471 (2018) 759-776. 
[19] V. Barve, F. Ahmed, S. Adsule, S. Banerjee, S. Kulkarni, P. Katiyar, C. E. Anson, A. K. Powell, S. Padhye, F. H. Sarkar, Synthesis, molecular characterization, and biological activity of novel synthetic derivatives of chromen-4-one in human cancer cells. J. Med. Chem. 49 (2006) 3800-3808.

[20] G. Kalaiarasi, S. R. J. Rajkumar, S. Dharani, V. M. Lynch, R. Prabhakaran, Synthesis, spectral characterization and biological evaluation of some copper(II) complexes containing 4-oxo-4H-chromene-3-carbaldehyde-4(N)-substituted thiosemicarbazones. Inorg. Chim. Acta. 471 (2018) 759-776.

[21] F. Arjmand, Z. Afsan, T. Roisnel, Design, synthesis and characterization of novel chromone based-copper(II) antitumor agents with N,N-donor ligands: comparative DNA/RNA binding profile and cytotoxicity. RSC Adv. 8 (2018) 37375-37390.

[22] (a) P. Politzer, J. S. Murray, Halogen bonding: an electrostatically-driven highly directional noncovalent interaction. Springer (2009) 149-163; (b) P. Politzer, J. S. Murray, An Overview of Strengths and Directionalities of Noncovalent Interactions: $\sigma$ Holes and $\pi$-Holes .Crystals (2019), 9, 165.

[23] A. J. Parker, J. Stewart, K. J. Donald, C. A. Parish, Halogen bonding in DNA base pairs. J. Am. Chem. Soc. 134 (2012) 5165-5172.

[24] J.S Murray, P. Lane, T Clark, K.E Riley, P. Politzer, $\sigma$-Holes, $\pi$-Holes and Electrostatically-Driven Interactions. J. Mol. Model. (2012), 18, 541-548.

[25] Z. P. Shields, J. S. Murray, P. Politzer, Directional tendencies of halogen and hydrogen bonds. Int. J. Quantum Chem. 110 (2010) 2823-2832;(b) P Politzer, J.S Murray, T Clark, G. Resnati, The $\sigma$-Hole Revisited. Phys. Chem. Chem. Phys. 19 (2017), 32166-32178. 
[26] M. Shebl, O. M. I. Adly, A. Taha, N. N. Elabd, Structural variety in copper (II) complexes of 3-formylchromone: Synthesis, spectral, thermal, molecular modeling and biological studies. J. Mol. Struct. 1147 (2017) 438-451.

[27] I. Yousuf, F. Arjmand, S. Tabassum, L. Toupet, R. A. Khan, M. A. Siddiqui, Mechanistic insights into a novel chromone-appended $\mathrm{Cu}(\mathrm{ii})$ anticancer drug entity: in vitro binding profile with DNA/RNA substrates and cytotoxic activity against MCF-7 and HepG2 cancer cells. Dalton Trans. 44 (2015) 10330-10342.

[28] S. M. Morgan, M. A. Diab, A. Z. El-Sonbati, Supramolecular assembly of hydrogen bonding, ESR studies and theoretical calculations of $\mathrm{Cu}$ (II) complexes. Appl. Organomet. Chem. 32 (2018) e4504.

[29] A. Z. El-Sonbati, W. H. Mahmoud, G. G. Mohamed, M. A. Diab, S. M. Morgan, S. Y. Abbas, Synthesis, characterization of Schiff base metal complexes and their biological investigation. Appl. Organomet. Chem. 33 (2019) e5048.

[30] M. Sharma, M. Ganeshpandian, M. Majumder, A. Tamilarasan, M. Sharma, R. Mukhopadhyay, N.S. Islam M. Palaniandavar, Octahedral copper (ii)-diimine complexes of triethylenetetramine: effect of stereochemical fluxionality and ligand hydrophobicity on $\mathrm{Cu} \mathrm{II} / \mathrm{Cu} \mathrm{I}$ redox, DNA binding and cleavage, cytotoxicity and apoptosis-inducing ability. Dalton Trans. 49 (2020) 8282-8297.

[31] M. Jiang, Y.-T. Li, Z.-Y. Wu, Z.-Q. Liu, C.-W. Yan, Synthesis, crystal structure, cytotoxic activities and DNA-binding properties of new binuclear copper(II) complexes bridged by $\mathrm{N}, \mathrm{N}^{\prime}$-bis(N-hydroxyethylaminoethyl)oxamide. J. Inorg. Biochem. 103 (2009) 833-844. 
B. J. Pages, D. L. Ang, E. P. Wright, J. R. Aldrich-Wright, Metal complex interactions with DNA. Dalton Trans. 44 (2015) 3505. complexes with NNO ligands: synthesis, crystal structures, DNA cleavage, and anticancer activities. Dalton Trans. 48 (2019) 17925-17935.

A. Wolfe, G. H. Shimer, Jr., T. Meehan, Polycyclic aromatic hydrocarbons physically intercalate into duplex regions of denatured DNA. Biochemistry 26 (1987) 6392-6396. The halogen bond in the design of functional supramolecular materials: recent advances

[35] A. Priimagi, G. Cavallo, P. Metrangolo, G. Resnati,. Acc. Chem. res. 46 (2013) 2686-2695.

[36] M. R. Scholfield, C. M. V. Zanden, M. Carter, P. S. Ho, Halogen bonding (X-bonding): A biological perspective. Protein Sci. 22 (2013) 139-152.

[37] E. F. Healy, Quantitative determination of DNA-ligand binding using fluorescence spectroscopy. J. Chem. Educ. 84 (2007) 1304-1307.

[38] M. Alagesan, N.S. Bhuvanesh, N. Dharmaraj, Potentially cytotoxic new copper (II) hydrazone complexes: synthesis, crystal structure and biological properties. Dalton Trans., 42 (2013) 7210-7223.

[39] A. Draksharapu, A. J. Boersma, M. Leising, A. Meetsma, W. R. Browne, G. Roelfes, Binding of copper(ii) polypyridyl complexes to DNA and consequences for DNA-based asymmetric catalysis. Dalton Trans. 44 (2015) 3647-3655.

[40] A. Raja, V. Rajendiran, P. U. Maheswari, R. Balamurugan, C. A. Kilner, M. A. Halcrow, M. Palaniandavar, Copper (II) complexes of tridentate 
pyridylmethylethylenediamines: role of ligand steric hindrance on DNA binding and cleavage. J. Inorg. Biochem. 99 (2005) 1717-1732.

[41] F. Arjmand, M. Aziz, S. Tabassum, Cyclic voltammetry-an electrochemical approach to study metal-based potential antitumor drug-DNA interaction. Curr. Anal. Chem. 7 (2011) 71-79.

[42] K.N. Aneesrahman, G. Rohini, N.S. Bhuvanesh, S. Sundararaj, M. Musthafa, A. Sreekanth, In Vitro Biomolecular Interaction Studies and Cytotoxic Activities of Newly Synthesised Copper (II) Complexes Bearing 2-Hydroxynaphthaldehyde-Based Thiosemicarbazone. Chemistry Select, 3 (2018) 8118-8130.

[43] F. Bisceglie, S. Pinelli, R. Alinovi, M. Goldoni, A. Mutt, A. Camerini, L. Piola, P. Tarasconi, G. Pelosi, Cinnamaldehyde and cuminaldehyde thiosemicarbazones and their copper (II) and nickel (II) complexes: A study to understand their biological activity. J. Inorg. Biochem. 140 (2014) 111-125.

[44] V. A. Bloomfield, DNA condensation by multivalent cations. Biopolymers 44 (1997) 269-282.

[45] J. Hormann, J. Malina, O. Lemke, M.J. Hülsey, S. Wedepohl, J. Potthoff, C. Schmidt, I. Ott, B.G. Keller, V. Brabec, N. Kulak, Multiply intercalator-substituted Cu (II) cyclen complexes as DNA condensers and DNA/RNA synthesis inhibitors. Inorg. Chem., 57 (2018) 5004-5012.

[46] V.B. Teif, K. Bohinc, Condensed DNA: condensing the concepts. Prog. Biophys. Mol. Biol. 105 (2011) 208-222.

[47] S. Zehra, T. Roisnel, F. Arjmand, Enantiomeric Amino Acid Schiff Base Copper(II) Complexes as a New Class of RNA-Targeted Metallo-Intercalators: Single X-ray 
Crystal Structural Details, Comparative in Vitro DNA/RNA Binding Profile, Cleavage, and Cytotoxicity. ACS Omega 4 (2019) 7691-7705.

[48] S. Rajalakshmi, M.S. Kiran, B.U. Nair, DNA condensation by copper (II) complexes and their anti-proliferative effect on cancerous and normal fibroblast cells. Eur. J. Med. Chem. 80 (2014) 393-406.

[49] Y. Gilad, H. Senderowitz, Docking studies on DNA intercalators. J. Chem. Inf. Model. 54 (2014) 96-107.

[50] X.B. Fu, D.D. Liu, Y. Lin, W. Hu, Z.W. Mao, X.Y. Le, Water-soluble DNA minor groove binders as potential chemotherapeutic agents: synthesis, characterization, DNA binding and cleavage, antioxidation, cytotoxicity and HSA interactions. Dalton Trans. 43 (2014) 8721-8737.

[51] M. Z. Hernandes, S. M. T. Cavalcanti, D. R. M. Moreira, J. de Azevedo, W. Filgueira, A. C. L. Leite, Halogen atoms in the modern medicinal chemistry: hints for the drug design. Curr. Drug Targets 11 (2010) 303-314.

[52] Y. N. Mabkhot, F. D. Aldawsari, S. S. Al-Showiman, A. Barakat, S. M. Soliman, M. I. Choudhary, T. B. Hadda, Novel enaminone derived from thieno [2,3-b] thiene: Synthesis, x-ray crystal structure, HOMO, LUMO, NBO analyses and biological activity. Chem. Cent. J. 9 (2015) 24.

[53] W. J. Lian, X. T. Wang, C. Z. Xie, H. Tian, X. Q. Song, H. T. Pan, X. Qiao, J. Y. $\mathrm{Xu}$, Mixed-ligand copper (II) Schiff base complexes: the role of the co-ligand in DNA binding, DNA cleavage, protein binding and cytotoxicity. Dalton Trans. 45 (2016) 9073-9087 
[54] H. R. Siddique, M. Naime, M. Saleem, Lupeol, a novel androgen receptor inhibitor acts as a double-edged sword: Competitive binding as well as transcriptional inhibition (2011).

[55] Y. An, M.L. Tong, L.N. Ji, Z.W. Mao, Double-strand DNA cleavage by copper complexes of 2, 2'-dipyridyl with electropositive pendants. Dalton Trans., (2006) 20662071.

[56] M. Gonzalez-Alvarez, G. Alzuet, J. Borrás, B. Macías, A. Castineiras, Oxidative Cleavage of DNA by a New Ferromagnetic Linear Trinuclear Copper(II) Complex in the Presence of $\mathrm{H}_{2} \mathrm{O}_{2}$ /Sodium Ascorbate. Inorg. Chem. 42 (2003) 2992-2998.

[57] D. Mustard, D. W. Ritchie, Docking essential dynamics eigenstructures. Proteins 60 (2005) 269-274.

[58] G. Macindoe, L. Mavridis, V. Venkatraman, M. D. Devignes, D. W. Ritchie, HexServer: an FFT-based protein docking server powered by graphics processors. Nucleic Acids Res. 38 (2010) 445-449.

[59] F. Arjmand, M. Muddassir, Y. Zaidi, D. Ray, Design, synthesis and crystal structure determination of dinuclear copper-based potential chemotherapeutic drug entities; in vitro DNA binding, cleavage studies and an evaluation of genotoxicity by micronucleus test and comet assay. Med. Chem. Comm., 4(2013) 394-405.

[60] M. Chauhan, K. Banerjee, F. Arjmand, DNA binding studies of novel copper (II) complexes containing l-tryptophan as chiral auxiliary: in vitro antitumor activity of $\mathrm{Cu}-\mathrm{Sn}_{2}$ complex in human neuroblastoma cells. Inorg. Chem., 46 (2007) 3072-3082.

[61] A. L. Spek, PLATON Procedure, A Multipurpose Crystallographic Tool. Utrecht University, Utrecht, The Netherlands (1998). 


\section{Highlights}

- Substituted chromone Copper (II) complexes were synthesized and characterized.

- DFT computational studies were also performed.

- Electrophoretic studies revealed an oxidative cleavage pathway.

- Cytotoxicity was evaluated against the human liver carcinoma (Huh-7) and prostate cancer (DU-145) cell lines.

- Copper (II) complex 2 exhibited selective cytotoxicity against DU-145 cell line at $\mathrm{GI}_{50}$ $=1.6 \mu \mathrm{M}$. 